\title{
Siapa yang Perlu Dipertimbangkan? Menilai Kesejahteraan Manusia dalam Pengelolaan Hutan Lestari
}

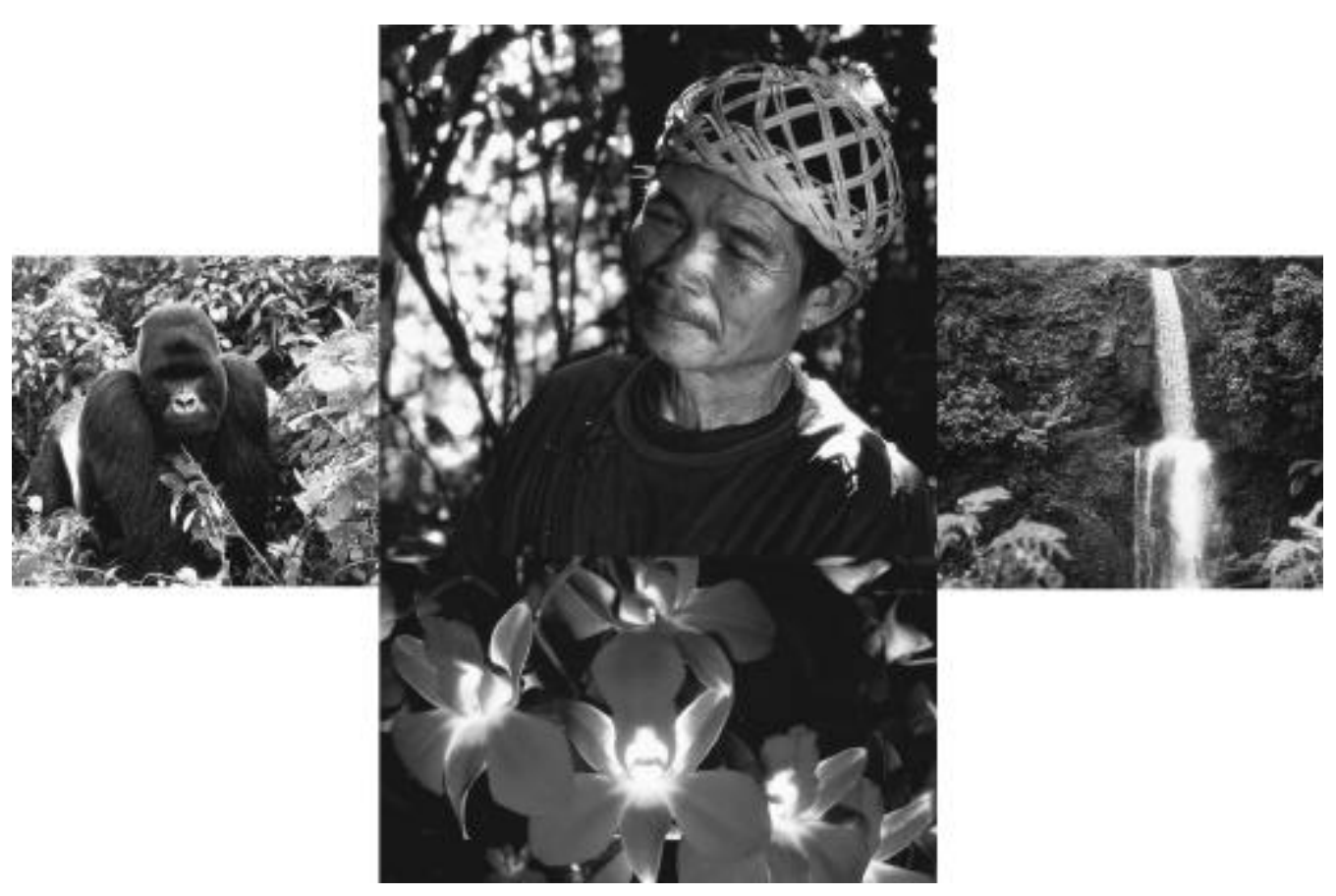

8 Perangkat Kriteria dan Indikator 


\title{
Siapa yang Perlu Dipertimbangkan? Menilai Kesejahteraan Manusia dalam Pengelolaan Hutan Lestari
}

Carol J. Pierce Colfer

\section{Bersama}

Ravi Prabhu, Mario Günter, Cynthia McDougall,

Noemi Miyasaka Porro dan Roberto Porro

\author{
Alih bahasa \\ Ani Kartikasari dan Yusak Pamei
}

Q Perangkat Kriteria dan Indikator 
(C) 1999 oleh Center for International Forestry Research

Dicetak oleh SMK GrafikaMardi Yuana, Bogor

Fotografi

Gorilla g. beringei oleh Tim Geer (WWF)

Air terjun, Indonesia oleh Susan Archibald

Seorang pemburu suku Kenyah, TanahMerah, Indonesia oleh Alain Compost

Dendrobium sp. (Anggrek liar) oleh Pliono Sist

Para penulis ingin menyatakan penghargaan kepada Herlina Hartanto, Herry Purnomo, Daju Pradnja Resosudarmo, Rahayu Koesnadi, Agus Salim, Abdurrahman Syebubakar, Meilinda Wan dan Yurdi Yasmi yang melakukan pengecekan kualitas terjemahan seri perangkat ini, dan juga kepada Meiske D. Tapilatu dan Dwiati Novita Rini yang melakukan pengecekan selama proses persiapan pencetakan.

ISBN: 979-8764-40-4

Diterbitkan oleh

Center for International Forestry Research (CIFOR)

Alamat: POBox6596JKPWB, Jakarta 10065, Indonesia

Telepon: +62-251-622 622 Fax: +62-251-622 100

E-mail: cifor@cgiar.org

WWW: http://www.cgiar.org/cifor

Dengan dukungan dana dari

The EuropeanCommission

Anggaran B7-6021 yang berkaitan dengan Hutan Tropis

Brusel, Belgia

Deutsche Gesellschaft für Technische Zusammenarbeit (GTZ) GmbH

Eschborn, Jerman

United StatesAgency for InternationalDevelopment (USAID)

Washington D.C., Amerika Serikat

Pencetakan edisi bahasa Indonesia ini sebagian besar didanai oleh kantor Ford Foundation di Indonesia. 


\section{Seri Perangkat K\&I}

\begin{tabular}{|c|c|}
\hline rangkatK\&INo. 1 & $\begin{array}{l}\text { Panduan untuk Pengembangan, Pengujian dan Pemilihan } \\
\text { Kriteria dan Indikator untuk PengelolaanHutanLestari } \\
\text { Prabhu, R.,Colfer,C.J.P. dan Dudley, R.G. }\end{array}$ \\
\hline SINo.2 & $\begin{array}{l}\text { Acuan Generik Kriteria dan Indikator CIFOR } \\
\text { Tim KEI CIFOR }\end{array}$ \\
\hline katK\&INo.3 & $\begin{array}{l}\text { Perangkat Modifikasi dan Adaptasi Kriteria dan Indikator } \\
\text { (CD-ROM) } \\
\text { Prabhu, R.,Haggith,M.,Purnomo, H., Rizal, A., Sukadri, D., } \\
\text { Taylor, J. dan Yasmi, Y. }\end{array}$ \\
\hline
\end{tabular}

\begin{tabular}{ll}
\hline PerangkatK\&INo.4 & Panduan IndukKriteria dan IndikatorCIFOR \\
& McDougall, C., Isbadi, I.R., Santoso, L., Corless, M. dan \\
& Purnomo,H.(ed.) \\
\hline
\end{tabular}

PerangkatK\&INo.5 Panduan PenilaianDasarKesejahteraanManusia

Colfer, C.J.P., Brocklesby, M.A., Diaw, C., Etuge, P., Günter, M., Harwell, E., McDougall, C., Porro, N.M., Porro, R., Prabhu, R., Salim, A., Sardjono, M.A., Tchikangwa, B., Tiani,A.M., Wadley, R.L., Woelfel, J. dan Wollenberg, E.

PerangkatK\&INo.6 Panduan Pendamping Penilaian Dasar Kesejahteraan Manusia

Colfer, C.J.P., Brocklesby, M.A., Diaw, C., Etuge, P., Günter, M., Harwell, E., McDougall, C., Porro, N.M., Porro, R., Prabhu, R., Salim, A., Sardjono, M.A., Tchikangwa, B., Tiani,A.M., Wadley, R.L., Woelfel, J. dan Wollenberg, E.

PerangkatK\&INo.7 Panduan Cara Pemberian Skor dan Analisis untukMenilai KesejahteraanManusia

Salim, A.danColfer,C.J.P., denganMcDougall,C.

$\overline{\text { PerangkatK\&INo.8 Siapa yang Perlu Dipertimbangkan? Menilai Kesejahtera- }}$ anManusia dalam PengelolaanHutanLestari

Colfer, C.J.P., Prabhu, R., Günter, M., McDougall, C., Porro, N.M. dan Porro, R.

PerangkatK\&INo.9 Panduan untuk Menerapkan Analisis Multikriteria dalam Menilai Kriteria dan Indikator

Mendoza, G.A., danMacoun, P. dengan Prabhu, R., Sukadri, D., Purnomo, danHartanto, $\mathrm{H}$.

PerangkatK\&INo.10 Metodologi untuk Menilai Indikator Ekologis dalam PengelolaanHutanLestari (dalam persiapan) 


\section{DAFTAR ISI}

Abstrak

1. MENGAPA PERLU PEMBEDAAN? ........................................................ 1

2. DIMENSI-DIMENSI MANUSIA YANG TERKAIT DENGAN PENGELOLAAN HUTAN LESTARI ................................................ 9

Kedekatan dengan Hutan ......................................................................... 10

Hak-hak Masyarakat Lokal .................................................................. 11

Ketergantungan ........................................................................... 12

Kemiskinan .......................................................................................... 13

Pengetahuan Lokal ............................................................................ 14

Integrasi Hutan/Budaya ................................................................... 14

Defisit Kekuasaan ................................................................................. 15

3. MEMBEDAKAN PARA PENGELOLA HUTAN DARI STAKEHOLDER LAINNYA ....................................................................................... 19

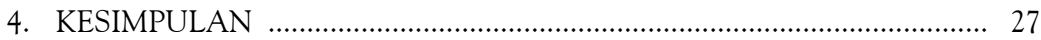

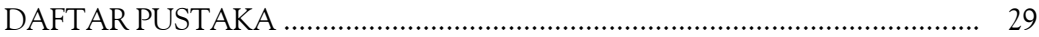

LAMPIRAN: Contoh Stakeholder dari Indonesia, Pantai Gading dan Amerika Serikat

DAFTAR TABEL

Tabel 1: Para stakeholder - Bushler Bay, Olympic National Forest, Washington, Amerika Serikat [Rekonstruksi mulai tahun 1970-1997] .................... 53

Tabel 2: Para stakeholder - Kalimantan Timur, Indonesia [Maret 1995] ........... 53 
Tabel 3: Para stakeholder - Bossematié, Pantai Gading [Juni 1995] 54

Tabel 4: Para stakeholder - Brasil [November 1995] ........................................... 55

Tabel 5: Para stakeholder - Trinidad [awal tahun 1998] .................................... 56

Tabel 6: Para stakeholder - Boise National Forest, Boise, Idaho, Amerika Serikat [Juni 1998]

Tabel 7: Para stakeholder - Porto de Moz dan Bom Jesus, Brasil [Agustus 1998] 


\begin{abstract}
ABSTRAK
Dalam makalah ini kami menyajikan suatu alat yaitu Matriks Siapa yang Perlu Dipertimbangkan, untuk membedakan pihak-pihak yang berkepentingan dengan pengelolaan hutan (forest actors), atau orang-orang yang kesejahteraannya terkait erat dengan pengelolaan hutan, dari stakeholder lainnya. Kami lebih memusatkan perhatian kepada para pihak yang terlibat dalam pengelolaan hutan dalam upaya untuk mengembangkan pengelolaan hutan lestari (PHL). Selain mengajukan tujuh dimensi untuk membedakan pihak-pihak ini dari stakeholder lainnya, kami memaparkan suatu teknik pemberian skor sederhana bagi para pengelola hutan resmi untuk menetapkan kesejahteraan siapa saja yang seharusnya menjadi bagian integral dari PHL di suatu lokasi tertentu. Dengan mengacu pada kriteria dan indikator (K\&I) yang ditetapkan oleh Center for International Forestry Research (CIFOR), kami membuat tiga set ilustratif tentang stakeholder di Indonesia, Pantai Gading dan Amerika Serikat (AS), dan melengkapinya dengan Matriks Siapa yang Perlu Dipertimbangkan dari tujuh pengujian yang disajikan dalam lampiran.
\end{abstract}




\section{Mengapa Perlu Pembedaan?}

Ada suatu tugas global yang muncul di kalangan para ilmuwan dan golongan lainnya untuk mengembangkan suatu sistem pengelolaan hutan lestari. Sebagai bagian dari pencapaian tujuan ini, sejak tahun 1994 CIFOR telah terlibat dalam mengidentifikasi prinsip-prinsip, kriteria dan sejumlah indikator untuk menilai tingkat kelestarian pengelolaan hutan. Kami mulai dengan melakukan seleksi dan pengujian lima perangkat utama kriteria dan indikator yang dikembangkan untuk sertifikasi ${ }^{1}$. Proses evaluasi ini meliputi pengujian di enam lokasi (Jerman, Indonesia, Pantai Gading, Brasil, Austria dan Kamerun). Fokus kami adalah kelestarian yang dimulai pada tingkat unit pengelolaan hutan, pada perusahaan kayu komersial, tetapi dengan berlalunya waktu, kami juga memasukkan aspek pengelolaan hutan oleh masyarakat, kawasan konservasi dan juga perkebunan.

Dalam proses pengembangan rumusan kerangka kerja konseptual untuk menyusun kriteria sosial dan indikator dalam lima sistem sertifikasi (Colfer dkk. 1995), kami segera menemukan kendala utama, yaitu tidak adanya mekanisme untukmembedakan pihak-pihak yang berkepentingan terhadap

${ }^{1}$ Perangkat kriteria dan indikator yang telah diuji meliputi Lembaga Ekolabel Indonesia (LEI), the British Soil Association's Woodmark, Rainforest Alliance's Smart Wood (AS), the German Initiative Tropenwald dan satu perangkat dari the Dutch Working Group of Expert on Sustainable ForestManagement. 
hutan yang dalam hal ini disebut stakeholder². Menurut kami, kelompok stakeholder ini mempunyai berbagai kepentingan, hak dan kewajiban yang berbeda, yang bisa ditempatkan di dalam satu kesatuan yang relevan dengan pengelolaan hutan sehari-hari ${ }^{3}$. Pandangan ini ditentang keras dalam sebuah pengujian terhadap sejumlah kriteria dan indikator di Boise National Forest (AS) baru-baru ini, di mana sebagian besar anggota tim pengujian $\mathrm{K} \& \mathrm{I}$ merasa bahwa seluruh warga AS mempunyai hak suara yang sama dalam pengelolaan hutan-hutan nasionalnya. Namun ada juga sebagian besar kolaborator kami yang menyetujui bahwa stakeholder yang berbeda mempunyai peran yang berbeda dalam PHL, beberapa di antaranya lebih banyak terlibat secara langsung dibandingkan dengan yang lain. Secara umum diterima bahwa tidak ada mekanisme yang digunakan oleh para pengelola resmi untuk membedakan kelompok-kelompok itu.

Bentuk awal kumpulan K\&I atau pedoman-pedoman yang telah diuji di CIFOR menentukan kondisi-kondisi khusus untuk membedakan berbagai kelompok masyarakat yang mempunyai pengaruh kuat terhadap hutan atau yang dipengaruhi oleh hutan. Sebagian besar pedoman memberikan syarat,

\footnotetext{
${ }^{2}$ Walau kini digunakan dalam literatur PHSL, pemakaian istilah ini tidak konsisten dengan definisi menurut kamus: 'seseorang yang dipercayai untuk menjaga/memelihara harta milik atau uang yang merupakan subyek dari proses pengadilan atau dari pertikaian di antara penuntut yang bersaing di mana sang pemilik mengklaim tidak ada hak atau kepentingan kepemilikan. [garis miring ditambahkan] (Webster's Third New International Dictionary 1993). Behan (1988) memakai istilah 'Constituents = para pemilik' dengan pengertian yang sama dengan apa yang kamimaksud dengan 'stakeholder'.

${ }^{3}$ Hal ini tidak berarti bahwa para stakeholder yang kaya dan berpengaruh seperti para pemilik $\mathrm{HPH}$ atau pemerintah tidak mempunyai pengaruh penting terhadap hutan, tetapi halinilebih ditujukan untuk mengidentifikasi stakeholder lokal yang secara khusus terlibat dalam pengelolaan hutan secara sambilan, dengan efek yang merugikan terhadap hutan-hutan dan kesejahteraan mereka sendiri.
} 
misalnya, bahwa hak-hak kepemilikan masyarakat ${ }^{4}$ dihormati. Berbagai hak 'lokal', 'tradisional', 'indijenus', 'kesukuan', 'orang miskin', 'masyarakat yang lemah', 'para pekerja', 'para pendatang' dan 'kelompok-kelompok masyarakat' dicantumkan dalam Set K\&I yang berbeda. Dalam rangka menguji tingkat ketepatan penerapan panduan ini, kami memerlukan cara yang lebih jelas untuk mengidentifikasi para pengguna hutan yang relevan. Sebagai contoh, siapa pemilik atau yang seharusnya memiliki hak-hak dan mendapatkan keuntungan dari hutan? Siapa yang wajib atau yang seharusnya mengemban tanggung jawab? Pertanyaan-pertanyaan ini sangat penting bukan hanya bagi kami dalam rangka melakukan pengujian, tetapi juga relevan bagi pengguna $\mathrm{K} \& \mathrm{I}$ untuk melakukan penilaian. $\mathrm{K} \& \mathrm{I}$ yang diterima oleh tim selalu mencakup syarat-syarat yang terkait dengan kesejahteraan masyarakat, khususnya penduduk yang tinggal di dalam dan di sekitar kawasan hutan yang dinilai. Semakin jauh kami melakukan proses pengujian dan pengembangan $K \& I$, semakin penting lagi untuk mengindentifikasi para stakeholder utama ini.

Hal lain yang muncul selama penelitian berlangsung adalah ketidakmungkinan memisahkan nilai-nilai kemanusiaan dari konsep kelestarian. Ketika kami memutuskan tentang apa yang hendak dilestarikan, kami melihat lagi sistem nilai kami - sehingga K\&I yang dipakai CIFOR sebagai basis mencerminkan nilai-nilai yang dianut berbagai kelompok yang menyeleksinya. Oleh karena itu perangkat yang disajikan di sini juga mencerminkan pengalaman dan nilai-nilai tertentu dari tim-tim yang mengujinya.

\footnotetext{
${ }^{4}$ Secara global, terdapat berbagai macam sistem dan legitimasi hukum yang berbeda dalam hal kepemilikan lahan dan cara-cara mendapatkannya. Berdasarkan penelitian, kami menyarankan agar dalam setiap masalah khusus yang menyangkut kepemilikan dan tata guna lahan, persoalan penting yang terkait dengan PHSL adalah keamanan akses antargenerasi terhadap sumber daya (bandingkan dengan Colfer dkk. 1997b, 1988).
} 
Pertanyaan-pertanyaan di atas (siapa yang memiliki hak-hak dan manfaat tersebut, tugas-tugas dan kewajiban-kewajiban yang mana?) menegaskan adanya dualitas yang merupakan ciri penghuni hutan dan hubungan mereka dengan hutan. Di satu sisi para penghuni hutan sering digambarkan sebagai korban ( bergantung kepada hutan, miskin, tidak berbudaya , kurang terurus ) yang menekankan kebutuhan-kebutuhan mereka dan mengesankan suatu kepasifan mereka; di sisi lain, mereka memiliki potensi aktif yang sama seperti yang dimiliki setiap orang sebagai pengguna hutan, perilaku yang berpengaruh positif sekaligus negatif terhadap lingkungan mereka. Kedua aspek inimemiliki implikasi terhadap kesejahteraanmasyarakat.

Semua stakeholder, menurut definisi kami sendiri, memiliki kepentingan terhadap hutan. Namun demikian, ada alasan etis dan pragmatis - menyejajarkan aspek-aspek pasif dan aktif dari perilaku manusia seperti disebutkan di atas - bagi para pengelola hutan resmi untuk lebih memperhatikan hubungan yang lebih dekat dengan beberapa stakeholder dibandingkan dengan pihak lain. ${ }^{5}$ Kami menemukan kedua argumen etis maupun pragmatis semakin diakui pada setiap tahap dan dalam setiap komponen dalam usaha kami untuk menentukan siapa yang perlu dipertimbangkan dalam PHL.

\footnotetext{
${ }^{5}$ Di sebagian besar perusahaan HPH yang kami kunjungi, kami temukan bahwa masyarakat setempat dipandang sebagai rintangan yang tidak terhindarkan dalam pemanenan kayu yang efisien. Pihak yang lebih berkuasa dan makmur seperti perusahaan HPH, khususnya, tidak secara serius mempedulikan kepentingan penduduk setempat. PHL, sebagaimana didefinisikan dalam K\&I CIFOR, menganjurkan agar pandangan ini diubah ke arah kerjasama di antara stakeholder - apakah itu berarti pengelolaan secara bersama untuk hutan tertentu atau pengelolaan secara paralel di lokasi-lokasi yang berbeda. Sifat perhatian perusahaan HPH terhadap para stakeholder akan bervariasi dari satu tempat ke tempat lainnya.
} 
Dari segi etis, semakin diakui bahwa banyak orang yang hidup di hutan tidak diperlakukan secara adil, bahwa sumber daya mereka telah dirampas oleh orang-orang atau lembaga-lembaga yang lebih kuat dan berkuasa dan bahwa kesejahteraan mereka telah dirugikan melalui berbagai cara (bandingkan dengan Charter of the Indigenous Tribal Peoples of the Tropical Forests 1992; World Bank 1991; Colchester 1993; dan sejumlah studi kasus seperti dilaporkan dalam Barber dkk. 1994; atauRichards 1993).

Dari segi pragmatis, beberapa orang memiliki kemungkinan yang lebih besar untuk mempengaruhi hutan secara langsung dibandingkan orang-orang lain. Kelompok orang seperti ini kami sebut para pengelola hutan , untuk menekankan kemampuan mereka mengelola hutan, selain menerima, atau gagal mendapatkan manfaat - dari hutan (lihat Vayda dkk. 1980 untuk mendapatkan penjelasan rinci dan perspektif secara utuh). Sementara itu istilah masyarakat yang bergantung pada hutan menekankan apa yang diterima orang dari hutan, pengelola hutan menekankan pihak-pihak yang memiliki hak, kewajiban dan tindakan potensial yang berkaitan dengan hutan. Kemampuan melakukan tindakan dan ketergantungan keduanya adalah elemen-elemen penting dalam hubungan antara manusia dan kelestarian hutan.

Selama tahap kedua proyek CIFOR, kami memusatkan perhatian untuk membuat penilaian-penilaian terhadap kesejahteraan manusia secara cepat, mudah dan dapat diandalkan dan lebih menyempurnakan alat-alat yang diuraikan di sini. Alat yang disebut Matriks Siapa yang Perlu Dipertimbangkan dirancang untuk membantu para pengelola resmi yang bergelut dengan pertanyaan-pertanyaan seperti: Siapa pihak lain yang berhak atas hutan ini? Kepada siapa kami harus bertanggung jawab? Untuk kesejahteraan siapa kami memberikan andil? Dari siapa kami dapat memperoleh 
bantuan kerjasama dalam mengelola hutan? Dalam bagian selanjutnya, kami menyarankan faktor-faktor yang perlu dipertimbangkan dalam mendefinisikan kelompok masyarakat yang relevan, sangat penting untuk diperhatikan dalammengelola suatu unit hutan secara lestari; dan kamimengajukan suatu mekanisme untuk mengidentifikasi kepentingan relatif dari berbagai kategori dalam masyarakat hutan tertentu. Dengan demikian, mekanisme ini juga memungkinkan kami untuk membuat batasan tentang siapa yang sering disebut orang yang bergantung pada hutan .

Matriks Siapa yang Perlu Dipertimbangkan , yang semula dibuat pada bulan Juni 1995, telah terbukti berguna secara praktis maupun teoritis. Tim CIFOR dan para kolaboratornya telah berulang kali memakai alat ini (di Indonesia, Pantai Gading, Brasil, Kamerun, Trinidad dan Amerika Serikat); para penilai hutan tertarik dengan matriks ini karena kesederhanaannya (seperti SGS Forestry, Rainforest Alliance, FSC); dan para pengelola hutan dalam lokakarya tentang K\&I juga berpendapat bahwa instrumen serupa memang diperlukan. Manfaat langsung matriks ini adalah untuk mempercepat penilaian terhadap pengelolaan hutan oleh suatu tim sertifikasi atau dalam kunjungan singkat untuk mengevaluasi suatu proyek. Namun para pengelola hutan juga telah mengemukakan kebingungan mereka tentang berbagai tanggung jawab mereka terhadap stakeholder yang berbeda. Suatu cara yang sederhana untuk mengidentifikasi siapa yang paling perlu dipertimbangkan pada tingkat unit pengelolaan hutan dapat membantu para pengelola setempat untuk mengelola hutan dengan lebih baik ${ }^{6}$. Penjelasan tentang faktor-faktor yang mempengaruhi hubungan masyarakat dengan

\footnotetext{
${ }^{6}$ Walaupun makalah ini disusun untuk para pengelola resmi - dalam rangka pengakuan terhadap realitas politik global - kami yakin bahwa sebagaimana keterlibatan penduduk setempat dalam pengelolaan hutan semakin dikenal dan diakui, maka proses identifikasi stakeholder inijugaakanmemperhatikanmereka secara langsung.
} 
hutan - juga penting dalam menentukan siapa yang perlu dipertimbangkan - memberikan kontribusi lebih besar terhadap pemahaman kita mengenai interaksi masyarakat dan hutan. Penyelidikan terhadap dilema/ masalah kehutanan saat ini, termasuk masalah konflik dalam kelompok dan di antara kelompok-kelompok akan meningkatkan pemahaman kita terhadap aspek-aspek keadilan dalam satu generasi yang pada akhirnya akan berdampak besar pula terhadap terwujudnya keadilan antargenerasi. Pengalaman kami memakai Matriks Siapa yang Perlu Dipertimbangkan menunjukkan bahwa alat ini sangat berguna sebagai suatu titik acuan berharga bagi langkah kerja selanjutnya.

Kerjasama di antara para stakeholder di masa depan akan membutuhkan kemampuan mereka untuk mengidentifikasikasi secara akurat tahap ini. Oleh karena itu, langkah awal ini merupakan tahap yang penting. Pekerjaan selanjutnya dengan orang-orang ini akan memerlukan perhatian yang lebih terfokus dalam hal perbedaan-perbedaan di dalam kelompok (seperti jender, umur, kemakmuran) dan terhadap interaksi antara para pengelola hutan dengan stakeholder penting lainnya. Pemeriksaan terhadap konflik-konflik di dalam kelompok atau antarkelompok akan meningkatkan pemahaman kita terhadap aspek-aspek keadilan dalam satu generasi, yang pada gilirannya berdampak besar terhadap terwujudnya keadilan antargenerasi. Günter menemukan bahwa Matriks Siapa yang Perlu Dipertimbangkan akan menjadi titik awal yang penting untuk menyelidiki hal-hal ini.

Pada bagian berikut (2), kami membahas ketujuh dimensi (yang mencerminkan keterkaitan masyarakat dengan hutan) yang kami percaya dapat memudahkan penempatan awal para stakeholder dalam suatu kerangka untuk melihat keterlibatan yang bermanfaat dalam pengelolaan hutan sehari-hari. Akhirnya, pada Bagian 3, kami menyarankan suatu teknik se- 
derhana dan langsung untuk mengidentifikasi para stakeholder yang kesejahteraannya sangat penting, baik secara etis maupun secara pragmatis dalam PHL.

Contoh 'Matriks Siapa yang Perlu Dipertimbangkan'

\begin{tabular}{|l|l|l|l|l|}
\hline & $\begin{array}{l}\text { Masyarakat } \\
\text { lokal }\end{array}$ & $\begin{array}{l}\text { Pekerja } \\
\text { kehutanan }\end{array}$ & $\begin{array}{l}\text { Perusahaan } \\
\text { HPH }\end{array}$ & $\begin{array}{l}\text { Pemerintah } \\
\text { lokal }\end{array}$ \\
\hline $\begin{array}{l}\text { Kedekatan dengan } \\
\text { hutan }\end{array}$ & & & & \\
\hline Hak-hak yang sudah ada & & & & \\
\hline Ketergantungan & & & & \\
\hline Kemiskinan & & & & \\
\hline Pengetahuan lokal & & & & \\
\hline $\begin{array}{l}\text { Integrasi budaya/hutan } \\
\text { Defisit kekuasaan }\end{array}$ & & & & \\
\hline Nilai tengah & & & & \\
\hline
\end{tabular}

Dalam Lampiran, kami menyajikan sketsa-sketsa umum dari tiga keadaan yang berbeda, untuk menggambarkan tentang tata guna lahan, populasi, berbagai persoalan lokal dan kecenderungannya serta tentang stakeholder itu sendiri. Contoh-contoh ini meliputi HPH PT Kiani Lestari di Kalimantan Timur, hutan Bossematié di Pantai Gading, yang kurang kami kenal ${ }^{7}$ dan National Olympic Forest, salah satu kawasan hutan Amerika yang telah dikenal Colfer sejak tahun 1972.

\footnotetext{
${ }^{7}$ Kami mengambil contoh jangka panjang dari pengalaman para kolaborator CIFOR di Afrika Barat: Ahui Anvo, Heleen van Haaften, Charles Huttel, Jean Claude Koffi Konan, Patrice Mengin-Lecreulx dan Anatole N 'Guessan dalam analisis mereka terhadap penelitian di Pantai Gading dan kami berterima kasih untuk bantuanmereka yangsangat berarti.
} 


\section{Dimensi-Dimensi Manusia yang Terkait dengan Pengelolaan Hutan Lestari}

Untuk menetapkan aspek apa dalam kesejahteraan masyarakat yang paling penting dalam PHL pada tingkat unit pengelolaan hutan, diperlukan identifikasi elemen-elemen atau dimensi terpenting dalam hubungan masyarakat dan hutan. Tanpa pemahaman yang memadai tentang bagaimana masyarakat terkait (atau dapat dikaitkan) dengan hutan, maka penentuan kelompok masyarakat mana yang paling penting dalam pengelolaan hutan akan menemui banyak kendala.

Dalam pembahasan berikut, kami mengidentifikasi tujuh dimensi ${ }^{8}$ yang berkaitan dengan interaksi masyarakat dengan hutan, di mana stakeholder dapat ditempatkan berdasarkan faktor: kedekatan dengan hutan, hak-hak yang sudah ada, ketergantungan, kemiskinan, pengetahuan lokal, integrasi hutan/budaya dan defisit kekuasaan. Dimensi-dimensi ini dipandang sangat penting di beberapa hutan tertentu di Indonesia, Pantai Gading, Austria, Kamerun, Trinidad, AS dan Brasil. Dimensi-dimensi ini terkait erat dengan kesejahteraan manusia dan terhadap potensi kontribusi positif dan negatif masyarakat terhadap

\footnotetext{
${ }^{8}$ Dimensi-dimensi ini telah menjadi pokok diskusi penting. Semula kami menetapkan enam unsur (tidak termasuk 'kemiskinan'). Sebagian besar penelitian dilakukan tanpa faktor 'kemiskinan.' Menurut catatan Porro, dikeluarkannya unsur 'kemiskinan' tidak akan mengubah hasil penelitian. 'Kemiskinan' dimaksudkan untuk membedakan penduduk lokal dari pihak pemilik HPH yang juga 'bergantung' pada hutan. Kami juga pernah memasukkan 'etika konservasi' dan 'penggusuran' (keduanya untuk membedakan para pemukim dan masyarakat indijenus di hutan), dan mengombinasikan 'pengetahuan indijenus' dan 'hubungan hutan dan budaya' (karena pengetahuan indijenus mengenai hutan dapat dipertimbangkan sebagai bagian dari 'hubungan hutan dan budaya'). Para pengguna seharusnya dapat secara leluasa menambahkan dimensi-dimensi yangsesuai dengan konteksmereka.
} 
pengelolaan hutan. Semua dimensi ini mempunyai aspek pragmatis dan etis. Walaupun setiap dimensi ini dapat didefinisikan secara lebih rinci lagi, kami berpendapat bahwa definisi-definisi yang ada ini memadai untuk diterapkan oleh para pengelola hutan dan para penilai di lapangan.

\section{KEDEKATAN DENGAN HUTAN}

Kedekatan yang dimaksud di sini secara sederhana adalah kedekatan jarak dengan hutan. Kami menyadari masyarakat yang tinggal di dekat hutan memiliki potensi dampak cukup penting terhadap hutan. Jarak fisik yang dimaksud dalam kedekatan ini akan bervariasi dari satu hutan ke hutan lainnya, mengingat adanya perbedaan kemudahan akses terhadap hutan di berbagai tempat. Bushler Bay di Washington ditunjang oleh jaringan jalan yang sangat baik dan juga dengan sistem penyeberangan dengan ferry, yang menghubungkannya dengan kota Seattle dalam beberapa jam. Namun di Kalimantan Timur, perjalanan dari ibukota propinsi di Samarinda ke Batu Ampar (kamp HPH) dapat menghabiskan waktu delapan jam sampai dua hari. Di Trinidad, hampir setiap orang hidup tidak jauh dari hutan.

Masyarakat yang memiliki akses yang mudah terhadap hutan akan menguntungkan jika dilibatkan dalam pengelolaan hutan; dan memang benar, setelah melakukan penelitian jangka panjang tentang pengelolaan hutan lestari kami menyimpulkan bahwa mereka harus diberi peluang untuk terlibat lebih banyak. Masyarakat di sekitar hutan yang merasa dirinya tidak diikutsertakan juga memiliki kemampuan, secara langsung ataupun tidak, menyebabkan kerusakan hutan. Pustaka yang mendalam tentang dampak negatif terhadap lingkungan akibat pembangunan jalan di dalam kawasan hutan (misalnya, Mahar 1989; Moran 1981, 1990) merupakan contoh-contoh lain potensi masyarakat sekitar hutan untukmerusak hutan. 
Behan (1988) memberikan alasan-alasan yang meyakinkan terhadap pengelolaan oleh suatu konstituen ( masyarakat yang mengenal dan peduli, khususnya terhadap...hutan ), yang kebanyakan dari mereka menurut Behan merupakan kelompok yang secara georafis dekat dengan hutan. Behan juga mengangkat masalah penting: ada masyarakat yang mungkin mengenal dan peduli terhadap hutan, walaupun mereka tidak tinggal di dekat hutan. Behan membuktikan bahwa masyarakat seperti ini juga memiliki hak untuk terlibat dalam pengelolaan hutan, seperti kita seharusnyamenghormati hakhak orang lain untuk memilih tidak terlibat. Satu cara yang mungkin untuk menghadapi dilema ini adalah melibatkan kedekatan secara emosional, begitu juga secara fisik, dalam dimensi ini seperti yang dilakukan Günter di Trinidad. Dampak potensial relatif para pemilih yang secara fisik jauh/secara emosional dekat dibandingkan dengan para pemilih yang secara fisik dekat merupakan topik penelitian selanjutnya.

\section{HAK-HAK MASYARAKAT LOKAL}

Arti dari dimensi ini juga sangat berbeda dari satu tempat ke tempat lainnya (lihat Sayer 1991, misalnya; Fortmann dan Bruce 1988 atau Poffenberger 1990). Di banyak tempat, hutan yang terancam umumnya adalah sasaran konflik klaim tanah, bahkan sampai konflik paradigma tentang arti kepemilikan dan penggunaan lahan. Kadang masyarakat yang telah menempati kawasan tertentu selama beberapa dekade, abad bahkan milenium, akhirakhir ini hak tradisional mereka telah direbut atau sangat ditekan (bandingkan dengan Colchester 1993; Colfer bersamaDudley1993).

Jika ada masyarakat seperti ini di dekat atau di dalam hutan, pengakuan terhadap hak-hak mereka sangat penting, baik secara etis maupun pragmatis. Keadilan, yang dimaksud dalam konvensi international, mengharuskan hak masyarakat terhadap hutan diakui dan dihormati. Dari segi praktis, 
persepsi tentang ketidakadilan dapat menjadi sumber berbagai masalah, dari ketidakacuhan terhadap kebijakan hutan sampai pada peningkatan konflik, vandalisme dan kekerasan (bandingkan dengan Guha 1993, untuk contohcontoh dari India; Barber dkk. 1994 atau Peluso 1992, untuk contoh-contoh dari Indonesia; Richards 1993, untuk contoh-contoh dari Amazonia).

Walaupun menurut pengalaman kami (terutama di kawasan tropis), para stakeholder yang memiliki hak-hak yang sudah ada umumnya adalah masyarakat lokal, hak-hak yang sudah ada ini juga berlaku bagi stakeholder lainnya, seperti perusahaan HPH yang sudah lama beroperasi.

\section{KETERGANTUNGAN}

Dalam banyak kawasan berhutan terdapat masyarakat yang hidupnya bergantung pada berbagai barang dan jasa di hutan (lihatmakalah FAO tentang proyek Community Forestry, tentang ketergantungan terhadap hutan; koleksi makalah oleh Hladik dkk. 1993; koleksi Redford dan Padoch 1992). Masyarakat dapat berburu, menangkap ikan, mengumpulkan makanan, obat dan serat, atau melakukan agroforestri. Masyarakat seperti ini biasanya tidak banyak memiliki pilihan yang realistis untuk kelangsungan hidup mereka ${ }^{9}$ (bandingkan dengan Peluso 1991, 1993). Kebutuhan masyarakat yang penghidupannya bergantung pada hutan harus dipadukan ke dalam pengelolaan hutan lestari. Secara etis, akses masyarakat terhadap makanan merupakan pertimbangan penting. Secara praktis, masyarakat yang anaknya lapar kare-

\footnotetext{
${ }^{9}$ Dengan demikian, penting juga untuk tidak mengabaikan kemungkinan bahwa keberadaan/ ketersediaan pilihan lain dapat berubah di masa yang akan datang. Pertimbangan penting yang ada di sini adalah mereka yang bergantung pada hutan tidak digusur dari tempat mereka mencari nafkah/penghidupan secara dini dan paksa, bahwa mereka memiliki suara dalam menentukan kecepatan dan arah perubahan.
} 
na mereka tidak diberi akses terhadap hutan mungkin tidak akan menghormatibatas-batas hutan.

\section{KEMISKINAN}

Kemiskinan merupakan istilah relatif yang definisinya perlu disesuaikan untuk masing-masing lokasi. Kelompok-kelompok atau individu yang aksesnya terhadap sumber daya alam jauh lebih sedikit daripada stakeholder lainnya disebut miskin. Dalam banyak kasus, akses terhadap uang tunai merupakan salah satu faktor penting untuk menentukan kemiskinan. Namun jika di suatu tempat uang tunai merupakan barang langka, maka ukuran-ukuran lain yang mencerminkan standar hidup, seperti kondisi gizi, kualitas perumahan atau pemilikan barang-barang konsumsi, dapat dijadikan alat penilaian.

Sementara ketergantungan sifatnya dapat menjadi kurang informatif jika sumber daya hutan yang ada berkelimpahan, kemiskinan jelas menunjukkan adanya kekurangan. Perbedaan lokasi perlu diingat, karena kemiskinan di Amerika Serikat sangat berbeda dengan kemiskinan diAfrika.

Kemiskinan merupakan masalah etis yang penting karena mencerminkan perbandingan secara tidak memadai dari akses masyarakat terhadap sumber daya, dan mengandung implikasi serius bagi kesejahteraan mereka. Secara pragmatis kemiskinan mencerminkan distribusi yang tidak merata (global, regional dan/atau lokal) dan kondisi ini mengandung bahaya konflik dan masalah-masalah sosial dan lingkungan lainnya yang terkait dengan kemiskinan. 


\section{PENGETAHUAN LOKAL}

Masyarakat yang telah tinggal di kawasan hutan sering memiliki pengetahuan unik dan berguna berdasarkan pengalaman lokal jangka panjang mereka (lihat, misalnya, Banuri danMarglin 1993a; Clay 1988; Moran 1993; Posey 1992, 1993). Pengetahuan ini dapat mengenai binatang dan perilakunya, tumbuhan dan pengelolaannya, penggunaan bermacam hasil, teknik pemrosesan hasil hutan, dll. Pengetahuan lokal ini sangat bernilai, mengingat keterbatasan pengetahuan kita tentang ekologi dan kegunaan hutan (terutama hutan tropis). Pengetahuan ini juga mendukung fungsi penting dalam integrasi yang menguntungkan antara penduduk setempat dengan pengelolaan hutan. Pengakuan terhadap nilai dari pengetahuan lokal dan kegunaannya adalah alat yang berguna sekali untuk meningkatkan komunikasi dan kerjasama antara penduduk setempat dan para pengelola hutan lainnya, sertamemberdayakan masyarakat lokal.

\section{INTEGRASI HUTAN/BUDAYA}

Budaya atau cara hidup erat sekali hubungannya dengan lingkungan mereka $^{10}$, dan ini berlaku juga terhadap masyarakat hutan. Mungkin ada tempat-tempat keramat di dalam hutan, sistem-sistem simbolis yang memberi arti bagi kehidupan dan sangat erat dengan perasaan masyarakat tentang diri mereka, fungsi keamanan dari tumbuhan hutan selama musim paceklik, dan banyak sekali hubungan lainnya.

\footnotetext{
${ }^{10}$ Memang ada suatu teori yang disebut 'penentuan oleh lingkungan' yang menyatakan bahwa budaya sangat ditentukan oleh kondisi lingkungan di mana budaya ini berkembang. Harris (1968) memberikan suatu pendekatan yang lebih canggih yang menjadi dasar model-model ini,yangdisebut 'penentuan oleh teknik-lingkungan.'
} 
Ketika kita menerapkan pendekatan kita dalam melakukan identifikasi para pengguna hutan di hutan-hutan Amerika, ${ }^{11}$ jelas bahwa bagi para ahli lingkungan, konservasi hutan sangat berkaitan erat dengan sistem nilai dan pandangan dunia (bandingkan dengan Vail 1993, untuk pembahasan situasi serupa di Maine) - walaupun pandangan dunia ini mungkin secara sadar bersifat selektif dan kemungkinan besar tidak akan terjadi di dua tempat yang disajikan dalam lampiran.

Selama cara hidup penduduk terintegrasi dengan hutan, kelangsungan budaya mereka terancam oleh kehilangan hutan. Kehancuran budaya ini mempunyai dampak kemerosotan moral, pemecah belah dan perusakan secara umum terhadap masyarakat yang sangat berpengaruh (lihat, misalnya, Van Haaften dan Van de Vijver 1995; de Bruijn dan van Dijk 1995). Secara praktis kondisi ini juga berarti meningkatkan kemiskinan materi, berbagai penyakit mental dan fisik, dan berbagai masalah sosial (yang juga merupakan ciri kemiskinan). Oleh karena itu keragaman budaya juga mengalami kemerosotan.

\section{DEFISIT KEKUASAAN}

Dalam banyak kawasan, kekuasaan penduduk yang tinggal di dalam atau di dekat hutan lebih lemah dibandingkan dengan stakeholder lain (lihat Salafsky dkk. 1993, untuk pembahasan hal ini mengenai Kalimantan Barat; Smith dan Steel 1995 mengenai pembahasan tentang US Pacific North-

\footnotetext{
${ }^{11}$ Olympic National Forest di bagian barat Washington, yaitu di Olympic Peninsula, suatu hutan hujan di kawasan beriklim sedang; dan Boise National Forest North di Boise, Idaho, suatu habitat yangjauhlebihkering dan rentan terhadap kebakaran.
} 
west $).{ }^{12}$ Kekuasaan mungkin berakar pada pendidikan, kekayaan, hubungan dengan lembaga pemerintah, atau lembaga lokal yang diakui. ${ }^{13}$ Penduduk lokal misalnya, kekuasaannya jauh lebih rendah daripada para pegawai $\mathrm{HPH}$ (berdasarkan faktor-faktor seperti praduga, koneksi dengan penguasa, pendidikan formal dan kesamaan ciri-ciri sosial); atau masyarakat Dayak di Kalimantan umumnya memiliki kekuasaan yang lebih rendah daripada kalangan transmigran yang agama, bahasa dan budayanya sama dengan aparat pemerintah. Di mana defisit kekuasaan lokal terjadi, pengaruhnya mungkin merugikan hutan, karena penduduk tidak mempunyai cara-cara untuk melindungi sumber daya mereka dari tekanan luar (bandingkan dengan Banuri dan Marglin 1993b; Barber dkk. 1994); atau sumber penghidupan mereka sangat terganggu sehingga mereka terpaksa melakukan praktik-praktik yang merusak. Akibatnya mungkin berupa degradasi lingkungan dan juga penurunan kesejahteraan manusia.

Elemen lain yang terkait dengan masalah kekuasaan adalah tentang pengetahuan siapa yang dianggap penting (Ardener 1975; Colfer 1983; Colfer dan Wadley 1996; Jordan 1991, 1997) - persoalan yang berbeda dari keberadaan pengetahuan. Banuri dan Marglin (1993b), dalam pembahasan mereka tentang India, menjelaskan adanya suatu pola global yang umum, yang dalam banyak kasusmerugikan pengelolaan hutan lestari:

\footnotetext{
${ }^{12}$ Dove (1993) memiliki komentar yang menarik: 'Masalah bagi masyarakat hutan adalah karena mereka menghuni hutan yang merupakan sumber daya yang sangat diinginkan oleh kelompok-kelompok yang jauh lebih berkuasa daripada mereka (sedangkan masalahnya bagi hutan adalah karena didiami oleh masyarakat yang terlalu lemah untuk memaksakan kehendaknya dalam mengelola hutan secara lestari)'.

${ }^{13}$ Umans (1998) mengacu pada yang lain, pandangan yang lebih dinamis dan menarik mengenai kekuasaan, dengan implikasi yang penting untuk pengelolaan hutan bersama. Ia mengatakan 'kekuasaan tidak hanya dirasakan sebagai alat (sebagai perlengkapan dari pelaku) tetapi juga sebagai efek yang dihasilkan dan berkembang dalam jaringan para pelaku'.
} 
Dengan mencap masyarakat lokal terbelakang dan tidak peduli, dengan menyatakan bahwa praktik-praktik mereka merusak hutan, maka para pendukung sistem pengetahuan yang menonjol membuat suara masyarakat yang menantangmereka tidak akan didengar.

Pembungkaman suara masyarakat, secara sengaja atau tidak, berpotensi menimbulkan pengaruh yang berbahaya, seperti menurunkan kemampuan dan kemauan mereka untuk ikut serta dalam kerjasama pengelolaan hutan atau menurunkan akses pengelola formal terhadap pengetahuan yang berguna. 


\section{Membedakan Para Pengelola Hutan dari Stakeholder Lainnya}

Penetapan tingkat kepentingan relatif dari beragam stakeholder (untuk membantu para pengelola formal melaksanakan pengelolaan yang lebih baik) dan mengidentifikasi orang-orang yang tingkat ketergantungannya terhadap hutan cukup penting (untuk digunakan dalam usaha-usaha pengembangan dan konservasi secara lebih umum) dianggap sebagai tugas yang penting, bahkan kontroversial dalam kasus tertentu. Pada bagian ini, kami menyajikan garis besar suatu metode sederhana yang telah teruji paling sedikit di sepuluh keadaan hutan (berbeda) ${ }^{14}$ - untuk membedakan berbagai kelompok masyarakat tersebut. Kami juga menggambarkan berbagai cara berbeda yang kami pakai untuk menguji metode ini. Pada bagian berikutnya, kami akhiri dengan pembahasan menyangkut konsep-konsep dan metode lainnya yangmasihmerupakan teka-teki.

Kami telah memakai ketujuh dimensi yang mengaitkan hutan dengan masyarakat, yang garis besarnya diuraikan di atas, untuk menentukan stakeholder mana yang mungkin memerlukan lebih banyak perhatian khusus dari para pengelola formal pada tingkat unit pengelolaan hutan baik karena para stakeholder ini mungkin tidak memiliki hak atau hak-haknya terhadap manfaat hutan tidak diakui dan karena mereka mungkin terkena dampak

\footnotetext{
${ }^{14}$ Lokasi-lokasiinimeliputi:

- Indonesia: (1) HPH PT Kiani Lestari di Sungai Telen, (2) PT Inhutani II di Bulungan, Kaltim, dan (3) SuakaMargasatwaDanauSentarum,Kalimantan Barat;

- Kamerun: (4) Areal konsesi Sogenic danWijmadekatKribidiSamudera Atlantik;

- PantaiGading: (5)Hutan Lindung Bossematié, dekatAbengourou;

- Trinidad: (6) dipusatkan di hutan Tanteak, tetapi dilakukan di beberapa lokasi yang sesuai di seluruh negeri;

- Brasil: (7) Uruara di kawasan Transamazon dan (8) di Porto de Moz sepanjang Sungai Xingu, keduanya di bagian Timur wilayah Amazon; dan

- Amerika Serikat: (9) Olympic National Forest di negara bagian Washington dan (10) Boise National Forest di Idaho.
} 
langsung yang lebih besar terhadap hutan bila dibandingkan dengan stakeholder yang lain. Contoh-contoh yang ditunjukkan dalam lampiran menyajikan suatu tinjauan kualitatif untuk perbandingan keadaan sesungguhnya pada tempat dan keadaan baru yang berbeda.

Tabel 1-7 adalah matriks beberapa lokasi terpilih, yang pada kolom sisi kirinya dicantumkan berbagai dimensi; sedangkan pada lajur atas dicantumkan golongan stakeholder. Tiga di antara contoh-contoh ini berkaitan dengan konteks (keadaan) yang digambarkan pada lampiran. Dalam matriksmatriks ini, penilai telah menetapkan skor para stakeholder yang sesuai dengan nilai skor di mana untuk setiap dimensi secara umum dikaitkan dengan stakeholder masing-masing: Skor $1=$ tinggi, $2=$ sedang, $3=$ rendah dan var = bervariasi. Skor rata-rata dari tiap kolom (di luar skor-skor bervariasi ) dihitung pada lajur bagian bawah setiap tabel. Stakeholder telah disusun sedemikian rupa sehingga semakin ke kanan nilai tengah skor semakin meningkat. Nilai yang merupakan batas pembeda para pengelola hutan tampaknyamemiliki skor $<2$.

Versi pertama alat ini yang dipakai untuk membedakan pengelola hutan dari stakeholder lainnya, diuraikan dalam Colfer (1995), dibuat setelah diuji selama sebulan, dengan melakukan uji lapang terhadap K\&I secara lintas disiplin di HPH PT Kiani Lestari, yang membelah Sungai Telen di Kalimantan Timur, dan di Hutan Lindung Bossematié dekat Abengourou di bagian Timur Pantai Gading pada tahun1995. Penelitian dilanjutkan pada tahun 1995 dan 1996, di lokasi penelitian kami di perusahaan penebangan kayu Cemex, sepanjang Sungai Tapajos di sebelah Timur Amazon, Brasil; dan di kawasan penebangan hutan Wijma dan Sogenic di sebelah Timur Kribi di Barat daya Kamerun. Pada tahun 1998 selama sebulan, dilakukan uji lapang lintas disiplin di BoiseNational Forest di sebelah Barat Idaho, ASUtara.

Uji tambahan yang dilakukan ilmuwan sosial secara terpisah dilakukan di Olympic National Forest, Peninsula di Negara Bagian Washington, AS (1995, Colfer); Suaka Margasatwa Danau Sentarum yang dikelilingi oleh beberapa kawasan HPH di Kalimantan Barat (1996, Colfer, Reed Wadley dan Emily 
Harwell); kawasan HPH Inhutani II di Hutan Penelitian Bulungan Kalimantan Timur (1998, CynthiaMcDougall); dan di Uruara di dekat jalan raya lintas Amazon dan Porto deMoz di Sungai Xingu, keduanya di sebelah Timur wilayahAmazon, Brasil (1998, NoemiMiyasaka Porro danRobert Porro).

Proses pemberian skor semula melibatkan pembuatan perkiraan berdasarkan pengalaman lapang profesional dari kasus-kasus hutan konsesi di Kalimantan Timur dan Olympic National Forest. Di Pantai Gading, kami memberikan skor berdasarkan observasi-observasi lapang yang singkat (barangkali dapat dibandingkan dengan hasil studi sebuah tim sertifikasi). ${ }^{15}$ Hasil perkiraan ini kemudian dibahas dengan anggota tim lain untuk direvisi. Pada tahun 1995, 15 peserta dalam penutupan lokakarya tentang uji K\&I CIFOR di Belem menguji metode ini. Dalam kumpulan data ini, ada 17 stakeholder yang telah diidentifikasi, mencerminkan fakta bahwa peserta lokakarya berasal dari seluruh Brasil, dengan berbagai bentuk penggunaan hutan lokal dengan profil-profil penggunaan yang berbeda. Tampaknya metode ini dapat diterapkan mulai dari tingkat unit pengelolaan hutan sampai pada tingkat nasional.

Hasil yang telah dikumpulkan mendukung pendapat kami bahwa pengelola hutan merupakan stakeholder yang mendapat skor 2 atau kurang. (Namun demikian, kami merekomendasikan nilai skor ini sebagai acuan kasar, bukan sebagai nilai yang kaku.

Günter (1998), McDougall (1998) dan Porro \& Porro (1998) baru-baru ini menguji perangkat ini di Trinidad, di Hutan Penelitian Bulungan dan Brasil. Günter (1998) bertanya kepada para pakar lokal yang netral tentang kehutanan dan kelestarian ${ }^{16}$ untuk mengisi Matriks Siapa yang Perlu Dipertim-

\footnotetext{
${ }^{15}$ Seymour dkk., (1995) misalnya, hanya memerlukan 2-12 hari kunjungan lapang untuk melakukan Sistem Sertifikasi Ilmiah (SCS).

${ }^{16}$ Para pakar yang dilibatkan Günter berasal dari Komisi Ekonomi PBB untuk Amerika Latin dan Karibia, UNDP, Unit Pembangunan Ekonomi Berkelanjutan, Universitas West Indies, Asosiasi Pelestarian Hutan Karibia, Institut Pertanian dan Kehutanan Karibia Timur, Kerjasama Antar Institut PertanianAmerika danDivisiKehutanan.
} 
bangkan. Hasil penelitian itu kemudian dipakai untuk memilih kelompok masyarakat paling penting sebagai fokus penelitian disertasinya dalam pengelolaan hutan lestari (wiraswastawan, pekerja hutan yang memegang ijin HPH dan pekerja penggergajian).

Hasil penelitian McDougall (1998) berdasarkan instruksi-instruksi dalam panduan metode yang dikembangkan CIFOR, baru-baru ini diterbitkan dengan judul Panduan Penilaian Dasar Kesejahteraan Manusia (Basic Assessment Guide for Human Well-Being) (Colfer dkk. 1999a). Ia mencoba membuat Matriks Siapa yang Perlu Dipertimbangkan, berdasarkan hasilhasil metode Kelompok Sasaran sebelumnya yang dirancang untuk memperjelas berbagai peran stakeholder yang relevan. Ia menemukan bahwa para anggota kelompok sasaran (penduduk lokal) memperkecil kisaran stakeholder yang relevan sedemikian rupa sehingga pengguna hutan yang penting (seperti para pekerja hutan) dan kelompok stakeholder yang tidak relevan, disingkirkan terlebih dahulu sebelum relevansimereka dikaji.

Porro dan Porro (1998), seperti Colfer, lebih banyak mengandalkan penilaian mereka. Menurut mereka, metode ini sangat bermanfaat, tetapi mereka menekankan pentingnya kualifikasi penilai dalam membuat penilaian. Mereka juga kurang puas karena sifat penilaian yang statis dan tidak mampu mencerminkan kecenderungan atau aktivisme politis. Mereka mengakui bahwa penyatuan pertimbangan-pertimbangan serupa akan mempersulit penggunaan suatu alat yang dirancang agar sederhana dan mudah digunakan.

Hasil dari berbagai pengujian menunjukkan bahwa metode ini mantap dan bermanfaat serta mudah disesuaikan dengan kondisi setempat. Alat ini mudah dipakai, cepat dan hasilnya konsisten yang secara intuitif tampaknya cocok dengan semangat yang terlihat pada kriteria dan indikator untuk PHL.

Namun metode ini masih ada kekurangannya. Yang terpenting adalah bahwa penilaian terhadap PHL yang juga mempertimbangkan kesejahteraan 
masyarakat (seperti yang telah dilakukan oleh CIFOR) adalah semakin baik jika dikerjakan secara berulang-ulang. Matriks Siapa yang Perlu Dipertimbangkan dimaksudkan sebagai langkah awal dalam proses progresif yang secara perlahan dapat mempertajam pemahaman para penilai terhadap kondisi setempat. Penentuan bahwa satu kelompok etnis lokal atau lainnya, misalnya, adalah penting di lokasi tertentu, dapat menuntun kita pada pemeriksaan yang lebih hati-hati terhadap perbedaan-perbedaan pola penggunaan sumber daya oleh pria dan wanita di dalam kelompok suku itu. Variasi dalam kelompok - seperti umur, jender, kasta, mata pencaharian dapat menjadi sama besarnya (dan sama pentingnya) dengan variasi umum di antara stakeholder yang diperjelas dalam Matriks Siapa yang Perlu Dipertimbangkan. Ini terjadi bila pengelola resmi melangkah lebih jauh dari sekedar penilaian ke pemantauan atau pengelolaan bersama.

Pemecahan ketiga dilema yang terus menerus itu akan meningkatkan kepercayaan kita terhadap metode tersebut: menakar bobot setiap dimensi, metode pemberian skor dan penentuan nilai pemisah. Penentuan bobot relatif dari ketujuh dimensi menimbulkan kesulitan tertentu. Metode yang disajikan dalam tulisan ini, menganggap setiap dimensi memiliki bobot yang sama. Hal ini mungkin bukan suatu asumsi yang semestinya. ${ }^{17}$ Kemungkinan lain adalah bahwa dimensi-dimensi yang berbeda akan bervariasi tingkat kepentingannya sesuai konteksnya. Oleh karena itu, pembobotan itu sebaiknya ditentukan secara lokal. ${ }^{18}$ Kami sedang mengembangkan sebuah pendekatan analisis multikriteria yang akan membantu dalam konteks ini (Mendoza dkk. 1999).

${ }^{17}$ Walaupun kami telah meminta para kolaborator kami untuk mengemukakan hal ini, tidak ada satu pun yang mengusulkan bahwa pembobotan yang sama adalah tepat atau mungkin lebihmirip, bahwamasalah itumemang rumit.

${ }^{18}$ Seymour dkk., (1995) melaporkan bahwa satu dari sekian tugas semula dari tim Sistem Sertifikasi Ilmiah adalah untuk 'mempertimbangkan kasus khusus beberapa kriteria evaluasi dalam ketiga unsur-unsur program [kelestarian sumber daya hutan, pemeliharaan ekosistem hutan, serta keuangan dan kelestarian sosial ekonomi]...'. Mungkin diperlukan sejumlah percobaan serupa yang mendahului upaya-upaya untuk menentukan siapa yang perlu dipertimbangkan. 
Pemberian skor merupakan masalah lain. Dalam konteks sertifikasi, misalnya, pada tinjauan lapang selama sebulan di mana sejumlah evaluasi yang lain juga harus dilakukan - mungkin perkiraan waktu yang cukup leluasa untuk tim-tim penilai serupa - sistem pencatatan skor sederhana dengan nilai 1-3 adalah masuk akal. Seperti konsep semula, teknik pemberian skor adalah sangat mudah, dirancang untuk membantu para evaluator menilai kelestarian hutan yang ada untuk mengidentifikasi kelompok masyarakat yangmemerlukan perhatian khusus secara cepat dan mudah.

Namun demikian, untuk manfaat tertentu (khususnya apabila waktu penilaian yang tersedia lebih banyak), akan berguna dan memungkinkan untuk menyempurnakan sistem pemberian skor. ${ }^{19}$ Skala yang berbeda sudah dipertimbangkan. Beberapa rekan menyarankan skor 1-4, 1-5, 0-5, 1-10 dan 1-100 sebagai skala yang ideal. Beberapa di antaranya lebih suka untuk menyerahkan pilihan kepada responden dalam menentukan nilai tengah; yang lain lebih sukamenghindarinya.

Karena penyusunan dimensi-dimensi diperlakukan sebagai skala perbandingan (kontinu), sebenarnya tidak harus menggunakan skala nominal (daripada sekedar penyederhanaan). Kemungkinan lain yang tampaknya menarik secara teoritis melibatkan alokasi nilai 100 untuk seluruh matriks dan membiarkan para responden menempatkannya di antara kotak-kotak yang mereka rasa tepat. Pemberian skor secara serempak ini menghasilkan data yang lebih bisa diterima secara analisis statistik sekaligus menyajikan jalan keluar untuk mengatasi masalah pembobotan skor seperti diuraikan di atas (Maxwell dan Bart 1995). Masalahnya, tugas pengisian matriks menjadi lebih sulit. Bahkan cara ini juga mungkin secara tidak langsung menunjukkan tingkat ketepatan, yang sebenarnya tidak ada.

${ }^{19}$ Pemberian skor 'bervariasi' misalnya, tidak dapat diterima secara statistik. P. Venkateswarlu (seorang ahli statistik) menyarankan bahwa percobaan untuk menduga skor rata-rata bagi stakeholder yangberagam akan lebih diterima secara statistik. 
Akhirnya, titik pembeda/pembatas bagi pengguna hutan vs stakeholder lain, mungkin memerlukan pertimbangan lebih lanjut. Dalam seluruh pengujian yang kami amati, nilai '2' tampaknya merupakan nilai pembeda yang nyata dan konsisten. Namun keadaan ini tidak selalu terjadi dan seseorang mungkin ingin menentukan nilai yang lebih disukai secara lokal. Penetapan nilai inimerupakan topik penting untuk diteliti lebih lanjut.

Menempatkan stakeholder pada tempat mereka yang semestinya menurut ketujuh dimensi yang digunakan adalah - menurut pendapat kami - bermanfaat dalam menentukan tingkat relevansi mereka dengan PHL (termasuk dampaknya terhadap hutan maupun kesejahteraan manusia). Melalui berbagai pengujian metodologi, kami berpendapat bahwa metode ini cukup sederhana, tidak berbelit-belit dan secara umum bisa diterapkan. 


\section{Kesimpulan}

Pengembangan dan pengujian terhadap alat ini dilakukan saat uji lapang kriteria dan indikator dipakai dalam PHL. Salah satu dasar pemikiran yang kami jadikan acuan kerja adalah bahwa kesejahteraan manusia merupakan sesuatu yang penting, walaupun bukan merupakan prasyarat yang memadai bagi PHL. Dalam pengujian yang kami lakukan, kami perlu untuk mengidentifikasi golongan masyarakat yang mana, terutama di hutan-hutan tropis lembab yang kami kunjungi, layak mendapat perhatian kami. Dengan cepat kami ketahui bahwa pihak-pihak lain (para ilmuwan, para pengelola, pemberi sertifikat, evaluator) juga mau melakukan penilaian yang sama terhadap kondisimasyarakat di kawasan hutan secara cepat.

Matriks Siapa yang Perlu Dipertimbangkan sangat membantu kami. Metode ini sederhana dan cepat serta menyajikan titik acuan yang sangat baik untuk menilai berbagai keadaan masyarakat di hutan-hutan yang kami kunjungi. Matriks ini dapat mengidentifikasi masalah-masalah penting, memusatkan pikiran kami pada stakeholder lokal, dan memungkinkan kami untuk mempersingkat pekerjaan kami. Untuk tujuan-tujuan yang lebih bersifat akademis, perlu dilakukan penetapan definisi secara lebih tepat untuk istilah dimensi yang digunakan, termasuk pengukuran-pengukuran spesifik atau indikator-indikator untuk penilaian dimensi. Ada 2 faktor yangmengecilkan hati kami untuk menempuh jalur ini: 1) indikator-indikator serupa cenderung bervariasi menurut lokasi, menyebabkan berkurangnya manfaat/kegunaan instrumen ini, dan 2) para penilai kemungkinan besar tidak memiliki cukup waktu untuk melakukan pengukuran-pengukuran seperti yang dicantumkan.

Ketika matriks ini dipakai sebagai bagian dari program pemantauan internal atau untuk kepentingan pengelolaan bersama, indikator dimensi yang sesuai dengan kondisi lokal menjadi penting dan memungkinkan, dan penggambaran secara lebih tepat terhadap stakeholder (para kelompok pengguna dan 
subkategori yang lain) juga akan semakin dibutuhkan. Alat-alat tambahan yang perlu untuk membuat pembedaan secara lebih tepat di antara para pengelola hutan tersedia dalamColfer dkk. (1999a,b) . 


\section{Daftar Pustaka}

Agraria. 1976. Undang-undang Pokok Agraria (Undang-undang No. 5, Tahun 1960).DepartemenDalam Negeri, Direktorat Jenderal Agraria. Jakarta.

Aha Badou, A., Kouakaou, M.A.S., dan Eschlimann, J-P. 1992. Gestion traditionnelle de la forêt: Le cas Agni-Ndenye. Anthropological Studies Volume I, Rehabilitation of the BossematiéClassified Forest, Abengourou, Côte d'Ivoire.

Ardener, S. (ed.) 1975. Perceiving women. Malaby Press, London.

Banuri, T. dan Marglin, F.A. 1993a. A systems-of-knowledge analysis of deforestation, participation and management. Dalam: Banuri, T. dan Marglin, F.A. (ed.) Who will save the forests?: Knowledge, power and environmental destruction. Zed Books, London, h. 1-23.

Banuri, T. dan Marglin, F.A. 1993b. The environmental crisis and the space for alternatives: India, Finland and Maine. Dalam: Banuri, T. dan Marglin, F.A. (ed.) Who will save the forests?: Knowledge, power and environmental destruction. ZedBooks, London,h.24-52.

Barber, C.V., Johnson, N.C. dan Hafild, E. 1994. Breaking the logjam: Obstacles to forest policy reform in Indonesia and the United States. World Resources Institute. Washington, D. C.

Behan, R. W. 1988. A plea for constituency-based management. American Forests (July/August): 46-48.

Beukeboom, H. (1989). Provincial forest economic profiles. Ministry of Forestry/ FAO. Jakarta, Indonesia.

Brookfield, H. dan Padoch, C. (1994). Appreciating agrodiversity: A look at the dynamism and diversity of indigenous farming practices. Environment $36(5): 6-11$ dan 37-43.

Charter of the indigenous-tribal peoples of the tropical forests. 1992. Penang, Malaysia (15 February).

Clay, J.W. (1988). Indigenous people and tropical forests. Cultural Survival, Inc., Cambridge,Massachussetts.

Colchester, M. 1993. Forest peoples and Sustainability. Dalam: Colchester, M. dan Lohmann, L. (ed.) The struggle for land and the fate of the forests. World RainforestMovement/The Ecologist/ZedBooks,New York, h. 61-95. 
Colfer, C.J.P. 1977. Women's communication and family planning: The case of Bushler Bay. (Case Study \#4, reprinted 1978). East-West Communication Institute,Honolulu.

Colfer, C.J.P. 1983. On communication among 'unequals' International Journal of InterculturalCommunication 7:263-283.

Colfer, C.J.P. 1991. Toward sustainable agriculture in the humid tropics: Building on the experience in Indonesia. TropSoils Technical Bulletin No. 91/02. Raleigh,North Carolina.

Colfer, C.J.P. 1995. Who counts most in sustainable forest management? CIFOR Working Paper No. 7. CIFOR, Bogor, Indonesia.

Colfer, C.J.P. bersama Colfer, A.M. 1978. Inside Bushler Bay: Lifeways in counterpoint. Rural Sociology 42 (2): 204-220.

Colfer, C.J.P. bersama Dudley, R.G. 1993. Shifting cultivators of Indonesia: Marauders or managers of the forest? FAO Community Forestry Case Study Series No. 6., Roma, Italy.

Colfer, C.J.P. dan Wadley, R.L. 1996. Assessing 'participation' in forest management: Workable methods and unworkable assumptions. CIFOR Working Paper No. 12, CIFOR, Bogor, Indonesia.

Colfer, C.J.P. bersama Peluso, N. dan Chin, S.C. 1997a. Beyond slash and burn: Lessons from the Kenyah on management of Borneo's tropical rain forests. New York BotanicalGarden Press, New York.

Colfer, C.J.P. bersama Prabhu, R. dan Wollenberg, E. 1995. Principles, criteria and indicators: Applying Ockham's razor to the people-forestry link. CIFOR working PaperNo.8.CIFOR,Bogor, Indonesia.

Colfer, C.J.P., Wadley, R.L., Harwell, E., dan Prabhu, R. 1997b. Inter-generational access to resources: Developing Criteria and Indicators. CIFOR Working Paper No. 18. CIFOR, Bogor, Indonesia.

Colfer, C.J.P., Salim, A., Tiani,A.M., Tchikangwa, B., Sardjono,M.A.,dan Prabhu, R. 1998. Whose forest is this, anyway? C\&I on access to resources. Paper presented at the IUFRO Conference, 24-28 August,Melbourne, Australia.

Colfer, C.J.P., Brocklesby, M.A., Diaw, C., Etuge, P., Günter, M., Harwell, E., McDougall, C., Porro, N.M., Porro, R., Prabhu, R., Salim, A., Sardjono, M.A., 
Tchikangwa, B., Tiani, A.M., Wadley, R.L., Woelfel, J. dan Wollenberg, E.. 1999a. The BAG (Basic assessment guide for human well-being). Criteria \& Indicators Toolbox SeriesNo.5.CIFOR,Bogor, Indonesia.

Colfer, C.J.P., Brocklesby, M.A., Diaw, C., Etuge, P., Gunter, M., Harwell, E., McDougall, C., Porro, N.M., Porro, R., Prabhu, R., Salim, A., Sardjono, M.A., Tchikangwa, B., Tiani, A.M., Wadley, R.L., Woelfel, J. dan Wollenberg, E. 1999b. The Grab Bag: Supplementary Methods for Assessing Human Well Being. Criteria \& Indicators Toolbox SeriesNo.5. CIFOR, Bogor, Indonesia Davis, G. 1988. The Indonesian Transmigrants. Dalam: Denslow, J. dan Padoch, C. (ed.) People of the tropical rain forest. University of California Press, Berkeley, California, h. 143-153.

de Bruijn, M. dan van Dijk, H. 1995. Arid ways: Cultural understandings of insecurity in Fulbe society, Central Mali. Thela Publishers, Amsterdam, The Netherlands.

Dietrich, W. 1992). The final forest: The last great trees of the Pacific Northwest. Simon and Schuster, New York.

Dove, M. 1993. A revisionist view of tropical deforestation and development. Environmental Conservation 20:17-24.

Ehui, S.K. danHertel, T.W. 1989. Deforestation and agricultural productivity in the Côte d'Ivoire. American Journal of Agricultural Economics 71(3): 703-711.

Enloe, C. 1989. Bananas, beaches and bases: Making feminist sense of international politics. University of California Press, Berkeley, California.

Fairhead, J. dan Leach, M. 1998. Reframing deforestation, global analysis and local realities: Studies in West Africa. Routledge Press, London.

FAO. 1989. Report on field case studies of forest concessions. Ministry of Forestry/ FAO Field Document No. 1-5. Jakarta, Indonesia.

Fortmann, L. dan Bruce, J.W., (ed.) 1988. Whose trees? Proprietary dimensions of forestry. Westview Press, Boulder,Colorado.

Fulcher, M. 1982. Dayak and transmigration communities in East Kalimantan. Borneo Research Bulletin 14(1): 14-24. 
Guha, R. 1993. The malign encounter: The Chipko movement and competing visions of nature. Dalam: Banuri, T. dan Marglin, F.A. (ed.) Who will save the forest? Zed Books, London, h. 80-113.

Günter, M. 1998. Intergenerational equity and sharing of benefits on an island state. Draft paper for inclusion in: Colfer, C.J.P. (ed.) Local people in logged forest: Well-being under scrutiny. CIFOR, Bogor, Indonesia.

Harris,M.1968. The rise of anthropological theory: A history of theories of culture. Thomas Y. Crowell, New York.

Hladik, C.M.,Hladik,A.,Linares, O. F, Pagezy, H., Semple, A. danHadley,M.1993. Tropical forests, people and food. The Parthenon Pub. Group, Paris.

Jordan, B. 1991. Technology and social interaction: Notes on the achievement of authoritative knowledge in complex settings. Institute for Research on Learning, Palo Alto, California.

Jordan, B. 1997. Authoritative knowledge and its construction. Dalam: DavisFloyd, R. dan Sargent, C. (ed.) Childbirth and authoritative knowledge: Cross-cultural perspectives. University of California Press, Berkeley, California, h.55-79.

Kirk, R. bersama Franklin, J. 1992. The Olympic rain forest: An ecological web. University of Washington Press, Seattle.

Lien, C. 1991. Olympic battleground: The power politics of timber preservation. SierraClub, San Francisco.

Mahar, D.J. 1989. Government policies and deforestation in Brazil's Amazon region. World Wildlife Fund and the Conservation Foundation, Washington, D. C.

Maxwell, S. dan Bart, C. 1995. Beyond ranking: Exploring relative preferences in P/RRA. Notes on participatory learning and action, NO. 22. IIED SustainableAgriculture Programme, Brighton, UK.

McDougall, C. 1998. Report on test of social science methods, Long Loreh, Bulungan Research Forest. CIFOR internal report. CIFOR, Bogor, Indonesia.

Mendoza, G.A., dan Macoun, P. bersama Prabhu, R., Sukadri, D., Purnomo, H. dan Hartanto, H. 1999. Guidelines for applying multi-criteria analysis to the assessment of criteria and indicators. Criteria \& Indicators Toolbox Series No. 9. CIFOR, Bogor, Indonesia. 
Ministry of Forestry. 1967. Basic rules of forestry. Ministry of Forestry, Jakarta, Indonesia.

Miracle,M.P. 1970. The smallholder in agricultural policy and planning: Ghana and the Ivory Coast, 1960 to 1966. Journal ofDeveloping Areas 4:321-332.

Moran, E. 1981. Developing the Amazon. IndianaUniversity Press, Bloomington.

Moran, E. 1990. Private and public colonisation schemes in Amazonia. Dalam: Goodman, D. dan Hall, A. (ed.) The future of Amazonia. Mac-millan, London.

Moran, E. 1993. Managing Amazonian variability with indigenous knowledge. Dalam: Hladik, C.M. dkk., (ed.) Tropical forests, people and food. The Parthenon Pub. Group, Paris, h. 753-766.

Peluso, N. 1991. Forest dependence and vulnerability: The role of differential access to forests and trees. Report to the FAO Community ForestryUnit(May).

Peluso, N. 1992. Rich forests, poor people: Resource control and Resistance in Java. University of California Press, Berkeley, California.

Peluso, N. 1993. The impact of social and environmental change on forest management: A case study from West Kalimantan, Indonesia. FAO Community Forestry Case Study SeriesNo.8.

Poffenberger, M. (ed.) 1990. Keepers of the forest: Land management alternatives in Southeast Asia. Kumarian Press, WestHartford, Connecticut.

Porro, R. dan Porro, N.M. 1998. Methods for assessing social science criteria and indicators for the sustainable management of forests: Brazil test (Report on the development of sustainability assessment tools for the social science set of criteria and indicators). CIFOR Report. CIFOR, Bogor, Indonesia.

Posey, D. 1992. Interpreting and applying the reality of indigenous concepts: What is necessary to learn from the natives? Dalam:Redford, K.H. dan Padoch, C. (ed.) Conservation of neotropical Forests: Working from traditional resource use. ColumbiaUniversity Press, New York, h. 21-34.

Posey, D. 1993. The importance of semi-domesticated species in post-contact Amazonia: Effects of the Kayapo Indians on the dispersal of flora and fauna. Dalam: Haldik, C.M. dkk., (ed.) Tropical forests, people and food. The Parthenon Pub. Group, Paris, h. 63-71. 
Redford, K.H. dan Padoch, C. (ed.) 1992. Conservation of neotropical forests: Working from traditional resource use. Columbia University Press, New York.

Richards, E. M. 1993. Commercialization of non-timber forest products in Amazonia, NRI Socio-economics Series 2. Natural Resources Institute, Chatham,UK.

Sakuntaladewi, N. dan Amblani, M. 1989. Investigation of the steps needed to rehabilitate the areas of East Kalimantan seriously affected by fire. Deutsche Forstservice GmbH, FR-Report No. 11. Samarinda, East Kalimantan, Indonesia.

Salafsky, N.,Dugelby, B.L. dan Terborgh, J.W. 1993. Can extractive reserves save the rain forest? An ecological and socioeconomic comparison of nontimber forest product extraction systems in Peten, Guatemala, and West Kalimantan, Indonesia. Conservation Biology 7 (1): 39-52.

Sayer, J. 1991. Rainforest buffer zones: Guidelines for protected area managers. IUCN, Cambridge, U.K.

Seymour, R.S., Hrubes, R.J., dan Hammel, D. 1995. Certifying sustainable forestry: The evaluator's perspective. Journal of Forestry 93(4):26-29.

Smith, C.L. dan Steel, B.S. 1995. Core-periphery relationships of resource-based communities. Journal of the Community Development Society 26(1): 52 70.

SODEFOR. 1994a. Plan d'aménagement de la forêt Classée de la Bossematié (22,200 ha) 1995-2014. kfw/SODEFOR/gtz,Abengourou, Côte d'Ivoire.

SODEFOR. 1994b. Plan d'aménagement de la fôret Classée du Haut-Sassandra (102,400 ha) 1995-2014. Daloa-Vavouia, Côte d'Ivoire.

Umans, L. 1998. Participatory process analysis. Trees and PeopleNewsletter 35:1-15 (March).

Vail, D. 1993. The internal conflict: Contract logging, chainsaws and clear-cuts in Maine Forestry. Dalam: Banuri, T. danMarglin, F.A. (ed.) Whowillsavethe forests?: Knowledge, power and environmental destruction. Zed Books, London. 
van den Breemer, J.P.M. 1989. Yam cultivation and socio-ecological ideas in Aouan society, IvoryCoast. Sociologia Ruralis 29(3/4):265-79.

van den Breemer, J.P.M. 1992. Ideas and usage: Environment in Aouan society, Ivory Coast. Dalam: Croll, E. dan Parkin, D. (ed.) Bush base, forest farm: Culture, environment and development. Routledge, London, h. 97-109.

van Haaften, H. 1995. Final report/diary. Prepared for CIFOR's project on Testing Criteria and Indicators for Sustainable ForestManagement, Côte d'Ivoire.

vanHaaften, H. dan Van de Vijver, F.J.R. 1995. Psychological consequences of environmental degradation: An exploratory study in the Sahel. Internal paper, Department of Forestry, Wageningen, The Netherlands.

Vayda, A.P. dan Sahur, A. 1985. Forest clearing and pepper farming by Bugis migrants in East Kalimantan: Antecedents and impacts. Indonesia 39: 93 110.

Vayda, A.P., Colfer, C.J.P. dan Brotokusumo, M. 1980. Interactions between people and forests in East Kalimantan. Impact of Science on Society 30(3): 179. 190.

Wiersum, K. F. 1986. The effects of intensification of shifting cultivation in Africa on stabilizing land-use and forest conservation. Netherlands Journal of Agricultural Science 34: 485-488.

World Bank (1991). Policy on indigenous peoples. Operational Directive 4.20 (17 September). WorldBank, Washington,DC. 


\section{Lampiran: \\ Contoh Stakeholder dari Indonesia, Pantai Gading, dan Amerika Serikat}

Di tiga lokasi yang terpilih sebagai contoh, terdapat sejumlah kategori umum dan kategori khusus di antara para stakeholder. Warga negara nasional, konsumen, pejabat kehutanan, pengusaha skala kecil, dan pekerja $\mathrm{HPH}$ - dengan berbagai sifat yang khas - muncul di semua tempat. Di antara kelompokkelompok ini, hanya konsumen yang cukup sebanding dalam hal hubungan mereka dengan hutan, yang akan dibicarakan secara umum ${ }^{20}$ di sini.

Konsumen - Orang-orang ini menggunakan produk-produk yang dihasilkan oleh hutan. Hampir semua konsumen merasa khawatir tentang kemampuan untukmemelihara akses terhadap produk-produk seperti itu, dan beberapa orang khawatir tentang kelestarian pengelolaan hutan. Setiap lokasi mempunyai stakeholder tambahan dan juga ciri-ciri berbeda untuk stakeholder yang sama yang terdapat di tempat lain.

${ }^{20}$ Sifat umum itu mungkin, tentu saja, hanya menggambarkan fokus yang sampai sekarang masih lebih banyak memberikan perhatian kepada masyarakat yang dekat dengan unit pengelolaan hutan 


\section{A. HPH PT KIANI LESTARI DI KALIMANTAN TIMUR, INDO- NESIA $^{21}$}

Departemen Kehutanan Indonesia mengelola seluruh kawasan hutan di Indonesia atas nama negara. Untuk kawasan hutan Kalimantan yang diklasifikasikan sebagai hutan produksi, negara memberikan hak pengelolaan hutan bagi perusahaan swasta dan semi-swasta. Para pemegang HPH ini kemudian setuju untuk mengelola kawasan hutannya menurut hukum dan peraturan kehutanan yang berlaku di Indonesia. Di kawasan hutan Dipterocarpace dataran rendah milik PT Kiani Lestari seluas 340.000 hektar banyak tersebar desa-desa dari perkampungan Dayak (sebagian besar penduduk Kalimantan yang beragama Kristen dan masyarakat indijenus penganut animisme) dan perkampungan Kutai (indijenus, Muslim, orang Melayu), yang masing-masing memiliki sistem kepemilikan lahan, pengelolaan hutan, dan hak guna hutan tradisional. ${ }^{22}$ Sebagian besar masyarakat ini melakukan pengusahaan ladang seperti peladangan berpindah dalam kondisi kepadatan penduduk yang rendah (bersifat lestari sampai sebelum dekade terakhir).

21 olfer melakukan penelitian etnografi selama satu tahun di Long Segar, sebuah desa yang termasuk dalam ilayah konsesi HPH Kiani Lestari aktu itu milik Georgia Pacific pada tahun 1979-80, sebagai bagian dari proyekManusia dan Biosfer, Interaksi antara penduduk dengan hutan di Kalimantan Timur Penulis melakukan penelitian tambahan yang singkat pada tahun 1981, 1983, 1991, 1995 dan 1997 Kondisi kehutanan Indonesia sedang mengalami perubahan pesat, sehingga pengamatan-pengamatan ini mungkin tidak berlaku di masa yang akandatang

${ }^{22}$ Kepemilikan lahan di Indonesia, seperti di sebagian besar negara-negara tropis sudah lama merupakan masalah yang sulit Departemen Kehutanan mengklaim lahan hutan sebagai milik negara ndang-undang Pokok Kehutanan 1967 Departemen Pertanian mempunyai badan hukum mengenai hak adat dari penduduk lokal atau adat dan negara menghormati hak tersebut Agraria, 1976 Dua undang-undang ini saling bertentangan secara langsung Konflik lahan setempat yang diselesaikan kasus demi kasus sering merugikan mereka yang bertempat tinggal di dalam hutan ndang-undang Pokok Kehutanan ini sekarang sedang dalam tahap revisi, karena krisis politik dan ekonomi yang sedang dihadapi oleh Indonesia 
Kegiatan pertanian ini dilengkapi dengan pemanfaatan hutan (perburuan, penangkapan ikan, pengumpulan berbagai hasil hutan) dan migrasi musiman pria sebagai tenaga kerja harian. Orang-orang yang diketahui bermata pencaharian melalui konsensi di tahun 1989 adalah 20.308 (FAO 1989), dengan kepadatan penduduk kira-kira 60 orang/ $\mathrm{km}^{2}$ - jauh lebih tinggi daripada salah satu dari angka kepadatan tradisional atau rata-rata tingkat propinsi sebesar 7,7/ $\mathrm{km}^{2}$ (Beukeboom 1989).

Sepuluh ribu hektar dari kawasan ini telah dikembangkan menjadi lokasi transmigrasi untuk para transmigran dari pulau Jawa dan pulau-pulau lain di Indonesia yang padat penduduknya, yang dibiayai oleh pemerintah (Sakuntaladewi dan Amblani 1989). Lahan seluas 108.000 hektar dalam konsensi ini dikategorikan sebagai hutan konversi, yang sebagian besar akan dikembangkan untuk Hutan Tanaman Industri yang terutama ditanami Acacia mangium. Ada empat kelompok masyarakat transmigran HTI dalam kawasan ini. Mereka, kebanyakan berasal dari Jawa, mulai berdatangan pada tahun 1990 sebagai tenaga kerja yang dibutuhkan untuk mengembangkan area penanaman.

Perubahan yang terjadi meliputi pengurangan hutan alami secara drastis (dengan kemungkinan penurunan keanekaragaman hayati sebagai akibatnya), peningkatan jumlah penduduk secara cepat melalui migrasi ke dalam (terutama yang disponsori oleh pemerintah), penurunan yang cukup tinggi dalam hal integritas kebudayaan penduduk asli Kalimantan Timur, dan meningkatnya masalah di sektor pertanian yang berkaitan dengan kemerosotan kualitas lingkungan.

Dayak - Masyarakat ini (termasuk beberapa sub-kelompok, seperti Kenyah, Kayan, Bahau) mempraktekkan gaya hidup di sepanjang aliran sungai di dalam hutan.Mereka cenderung menempati daerah tertentu, meski- 
pun tidak selalu di lokasi desa tertentu, selama beberapa dasawarsa dan kadang beberapa abad. Sebagian masyarakat ini kurang mempunyai kekuasaan, uang dan pendidikan formal dibandingkan dengan anggota masyarakat lain yang lebih dominan. ${ }^{23}$ Sistem Dayak memiliki pengetahuan yang berguna tentang lingkungan mereka dan praktek-praktek pengelolaan hutan indijenus, yang sering diremehkan dan disalah mengerti oleh orang luar (lihat Brookfield dan Padoch 1994; Colfer bersama Peluso dan Chin 1997). Mereka juga biasanya mempunyai komitmen sampai tingkat tertentu untuk memelihara lingkungan hutan dan cara hidup mereka. Mereka sering merupakan pihak yang selalu 'kalah' dalam pendekatan pengelolaan hutan oleh yang berwenang.

Kutai - Adalah masyarakat penetap yang sudah lama, penduduk lokal dari Melayu, berlatar belakang kebudayaan Islam dan hidup di dalam masyarakat di sepanjang aliran sungai, berbaur dengan masyarakat Dayak. Sistem agroforestri mereka serupa dengan yang dimiliki masyarakat Dayak, dengan perbedaan utamanya adalah sistem Kutai agak lebih berorientasi komersial dan mereka lebih diterima oleh anggota masyarakat yang lebih dominan (karena kesamaan agama dan sejarah yang lebih menonjol - Kutaimempunyai Kesultanan di Tenggarong).

Transmigran - Mereka dipindahkan ke kawasan hutan dari tempat-tempat yang padat penduduknya (misalnya, Jawa, Timor, Flores) yang kebanyakan dicirikan oleh pertanian yang intensif. Mereka miskin, tidak banyak memiliki pilihan kegiatan ekonomi (bandingkan dengan Vayda

23 Masyarakat dominan mengacu kepada penduduk Muslim dari a a yang me akili sebagian besar penduduk di Indonesia dan mendominasi sistem pemerintahan, yang kepentingannyamendominasi kebijakan politik nasional 
dan Sahur 1988 tentang petani lada di Bugis; Colfer 1991 atau Davis 1988 tentang transmigran). Mereka umumnya datang bersama keluarga masing-masing, bertujuan untuk mengerjakan kegiatan pertanian menetap, sering atas dukungan pemerintah. Hubungan mereka dalam program transmigrasi dan (sering) karena kesamaan suku dengan pejabat pemerintah juga membuat mereka mempunyai lebih banyak pengaruh daripada penduduk asli di daerah tersebut. Transmigran yang baru datang, tidak mengenal cara-cara hidup dan sekaligus menjaga lingkungan hutan, cenderung lebih banyak ke arah gaya hidup pertanian. Beberapa orang datang ke daerah tersebut hanya untuk mengeksploitasinya kemudian pergi; dan yang lainnya bermaksud untuk menetap. Pandangan untuk melindungi alam dari para transmigran mungkin lebih terfokus pada 'pengelolaan tanah' daripada 'pengelolaan hutan'. Dalam suatu kurun waktu, mereka mungkin melakukan penyesuaian diri terhadap pengetahuan dan praktek-praktek yang dilakukan oleh masyarakat asli yang hidup di hutan (Fulcher 1982).

Pekerja HPH - HPH mempekerjakan beberapa orang pekerja. PT Kiani Lestari melaporkan adanya 543 pekerja pada tahun 1989 (FAO 1989). PT Alas Helau (perusahaan yang terkait, bekerja di kawasan hutan yang sama) mempunyai 725 pekerja pada tahun 1995, sebagian besar golongan suku Jawa (34\%), Kutai (23\%), Timor (13\%), dan Bugis (11\%). Para pria ini (kurang dari 5\% pekerja di Alas Helau adalah wanita) cenderung bekerja dalam kondisi penuh bahaya, sering dengan sedikit pengetahuan tentang praktek pembalakan hutan yang aman - baik untuk keselamatan mereka sendiri atau untuk perlindungan lingkungan. Sebagian besar wanita bekerja dalam sektor informal (termasuk pelacuran, dengan segala risiko buruk terhadap kesehatan fisik dan 
mental yang berkaitan dengan pekerjaan tersebut). ${ }^{24}$ Banyak pekerja $\mathrm{HPH}$ yang berada jauh dari keluarga mereka dan dari sumber pengawasan atau perlindungan sosial tradisionalnya, meskipun beberapa orangmenetap setelah kegiatan pembalakan hutan berakhir.

Pengusaha skala kecil - Mereka mungkin berwiraswasta atau bekerja untuk pemerintah. Mereka mempunyai informasi dan modal yang memungkinkan mereka untuk ikut serta dalam pemasaran dan pengolahan hasil-hasil hutan. Mereka mungkin juga terlibat dalam spekulasi lahan, mempekerjakan orang lain untuk menebang hutan (biasanya ilegal) ${ }^{25}$ dan/atau untuk membuka hutan yang kemudian mereka nyatakan sebagai milikmereka.

Pejabat HPH - Kelompok ini mencakup orang-orang yang berpendidikan, pejabat eselon yang lebih tinggi di perusahaan yang memungut hasil kayu dari hutan. Mereka umumnya datang dari daerah lain, kebanyakan dari perkotaan, dengan sedikit sekali pengetahuan keadaan

${ }^{24}$ Pembahasan Enloe 1989 tentang sejarah perkebunan selamamasapenjajahan di Indonesia ternyata relevan dengankeadaaandisini

Pelacuran menjadi sesuatu yang ajar di banyak ka asan hutan karena memang dirancang demikian, bukan suatu kebetulan belaka Ada beberapa catatan perdebatan para pengelola mengenai keuntungan dan kerugian pelacuran bagi perusahaan mereka Mereka berpendapat bah a terlalu sulit mendapatkan pekerja pria untuk bekerja di perkebunan jika mereka tidak menyediakan layanan seksual dari para anita Lagi pula, banyak pengelola HPH ini yang berpendapat bah a pelacuran merupakan suatu ketidaksusilaan yang tingkatnya lebih rendah daripada hubungan homo seksual antara para pekerja pria yang tidak didampingi anita Akhirnya dengan menyisihkan sebagian besar dari upah mereka untuk membayar jasa pelacuran, para pekerja pria semakin terjerat hutang sehingga membuat mereka lebih sukar untuk meninggalkan pekerjaan di sektor kehutanan ketika kontrak mereka berakhir

Dukungan serupa terhadap kebutuhan pelacuran dikemukakan oleh karya an perusahaan di Kalimantan,mungkin untuk alasan-alasanyangsama

${ }^{25}$ Di Kalimantan Barat, kami mengetahui satu kasus di mana kepala suku Iban merupakan mitra suatu perusahaan kayu, yang dalam hal ini pembalakan hutan yang mereka lakukan adalah sah 
setempat, baik tentang manusia atau mengenai lingkungannya, sedikit sekali. Mereka merupakan wakil nasional di hutan yang terpencil, dan mungkin mempunyai kekuatan yang cukup besar atas kehidupan masyarakat yang tinggal di dalam hutan.

Pejabat Departeman Kehutanan - Kelompok ini adalah para pejabat dari Departemen Kehutanan Indonesia. Mereka secara teknis bertanggung jawab terhadap pengelolaan hutan, tetapi tidak mempunyai sumber daya (sumber daya manusia atau finansial) untuk mengelola hutan secara efektif. Tugas resmi mereka termasuk untuk melindungi hutan dan, pada tingkat tertentu, memberikan perhatian terhadap kesejahteraan hidup masyarakat.

Pemerhati lingkungan - Kelompok ini adalah orang-orang yang berada di kota, yang peduli terhadap keadaan hutan-hutan di Indonesia, dan juga keadaan penduduknya. Mereka memberikan tekanan kepada pemerintah dan perusahaan untuk meningkatkan kelestarian kegiatan pembangunan hutan yangmereka lakukan.

Warga negara nasional - Kelompok ini mempunyai kepentingan dengan hutan, sebagai penerima segala pendapatan yang berasal dari hutan, yang sampai tingkat tertentu disalurkan melalui program-program pembangunan.

\section{B. HUTAN LINDUNG BOSSEMATIÉ, PANTAI GADING}

Hutan lindung Bossematié, di dekat Abengourou di sebelah timur Pantai Gading adalah suatu hutan lindung, artinya hutan tersebut berada di bawah wewenang hukum SODEFOR (lembaga pemerintah untuk mengelola hutan) dan secara hukum tidak diijinkan untuk digunakan dalam sektor pertanian bagi penduduk lokal (SODEFOR 1994a,b). Persepsi pemerintah 
tentang masalah kepemilikan (sudah ada sejak berada dalam kekuasaan Perancis) bertentangan dengan persepsi masyarakat indijenus tentang kepemilikan dan berbagai hak untuk memanfaatkan. Hutan ini sudah sangat rusak, dan berbagai usaha sedang dilakukan untuk merehabilitasinya, melalui penanaman berbagai jenis pohon komersial. Pembalakan hutan dan pertanian tidak diijinkan lagi di Bossematié.

Ehui dan Hertel (1989) melaporkan bahwa tingkat deforestasi di Pantai Gading adalah yang tertinggi di dunia $(300.000$ hektar atau $6,5 \%$ per tahun, dari hutan tropis yang semula luas seluruhnya 16 juta hektar). Mereka juga melaporkan bahwa sekitar 4,7 juta hektar Wilayah Hutan Permanen dan sekitar 731.750 hektar Wilayah Hutan Pedesaan pada tahun 1978, yang semakin banyak berkurang sejak tahun 1987 .

Di Pantai Gading, masalah-masalah kehutanan berkaitan dengan masalah pertanian. Berdasarkan studi pada tahun 1986, Wiersum mencatat terjadinya penurunan secara umum dalam kestabilan dan kelestarian sistem peladangan berpindah yang dilakukan masyarakat indijenus karena penurunan ketersediaan lahan untuk setiap ladang, penurunan nisbah, masa bera dan masa penanaman, dan sering juga karena menurunnya hasil panen dan keragaman tanaman . Ia juga mencatat bahwa perubahan dari peladangan berpindah menjadi penanaman tanaman perdagangan menetap tidak mendorong kestabilan tata guna lahan, tetapi justru lebih banyak menyebabkan perambahan hutan oleh kegiatan pertanian. Van den Breemer (1989) melaporkan keberadaan, di antara masyarakat Aouan (di dekat Bossematié), suatu sistem pemikiran dan peraturan, pada tingkat yang tidak disadari, mengarahkan masyarakat untuk memelihara keseimbangan ekologis. $\mathrm{Na}$ mun ia juga mencatat adanya proses perubahan sosial secara internal dengan dampak yang sangat merusak lingkungan . (Lihat Fairhead dan Leach 1998 untuk pandangan yang baru dan berbeda.) 
Di Bossematié, suatu proyek kerjasama Jerman-Pantai Gading bersama masyarakat sekitar hutan berusaha untuk mengembangkan beberapa pilihan sistem agroforestri mereka yang masih tradisional dengan menambah tanaman pangan yang dilengkapi dengan perburuan dan penanaman kakao dan kopi (Aha Badou dkk. 1992; SODEFOR 1994a). Proyek ini berusaha keras untuk mendorong keikutsertaan masyarakat lokal dalam perencanaan dan pelaksanakan kegiatan mereka (yang berbeda dengan prasangka sejarah nasional yang tidakmelibatkan petani, misalnya,Miracle 1970).

Tekanan jumlah penduduk lokal di hutan ini cukup besar, dari migrasi masuk (dari masyarakat Pantai Gading sendiri dan dari negara-negara yang berdekatan) dan dari peningkatan jumlah penduduk secara alami. Menurut perkiraan SODEFOR (1994a) pada tahun 1991 komposisi penduduk di Bossematié terdiri dari 62\% Agni (indijenus), 15\% yang bermigrasi dari luar Pantai Gading (Baoule), 21\% dari Burkina Faso dan 2\% dari Mali. Antara tahun 1975 dan 1988, SODEFOR mendapatkan bahwa rata-rata peningkatan jumlah penduduk di daerah tersebut adalah 4,7\% (dengan kenaikan tertinggi di beberapa daerah mencapai 11,2\%). Tingkat kepadatan penduduk berkisar antara 20-50 orang $/ \mathrm{km}^{2}$. Penanaman tanaman pangan dan tanaman keras di hutan Bossematié (baik legal maupun ilegal) sekarang berada di bawah pengawasan SODEFOR. Menggabungkan berbagai masalah kemiskinan penduduk lokal, migrasi masuk yang tidak terkendali dan peningkatan jumlah penduduk secara alami dengan berbagai upaya untuk merehabilitasi dan melindungi hutan lindung ini merupakan tantangan besar dalam pengelolaan hutan (bandingkan dengan van den Breemer 1992).

Banyak kategori stakeholder berikut hampir sama dengan yang ada di Indonesia. 
Agni (Autochtones), kelompok suku yang bertempat tinggal di dalam dan di dekat hutan. Kami menduga bahwa meskipun kelompok ini sudah tinggal di dalam kawasan dalam waktu yang lebih lama daripada kelompok lainnya, mereka tetap tidak mempunyai hak-hak yang kuat di hutan Bossematié (Aha Badou dkk. 1992). Namun suku Agni yang bersifat matrilinial ini mempunyai tradisi memanfaatkan hutan secara agroforestri (lihat van den Breemer 1992, tentang sistem Aouan yang serupa). Mereka juga kadang secara tradisional dan berkala memasukkan anggota dari kelompok-kelompok suku lain di dekatnya ke dalam sistem mereka. Sistem ini, selain memberikan tambahan tenaga kerja bagi suku Agni, juga menyediakan fungsi keamanan sosial yang lebih luas di daerah tersebut, juga memberikan pilihan mata pencaharian subsisten bagi mereka yang kelaparan.

Allochtones, penduduk Pantai Gading dari tempat lain yang tinggal di dalam atau di dekat hutan. Kelompok masyarakat ini pindah ke hutan pada waktu terjadi tekanan keadaan ekonomi atau lingkungan di daerah tempat asal mereka, untuk bekerja bagi kelompok masyarakat indijenus (di dalam atau di dekat hutan). Beberapa di antara kelompok ini berasal dari lain daerah yang sebelumnya berhutan, yang lain berasal dari padang rumput dan dari gurun pasir di sebelah utara sehingga mereka mempunyai pengetahuan indijenus tentang berbagai ekosistem dan pengelolaan hutan yang tingkatnya sangat bervariasi.

Allogens, orang asing, sebagian besar adalah pengungsi (karena alasan politik dan ekonomi) di dalam atau di dekat hutan. Peran mereka dalam pengelolaan hutan lestari serupa dengan peranan penduduk Pantai 
Gading dari daerah lain, hanya mereka mempunyai hak-hak yang lebih sedikit. ${ }^{26}$

Pekerja perusahaan kayu - Termasuk pembalak hutan yang bekerja untuk kontraktor (tacherons), di bawah perusahaan besar/SODEFOR dan pekerjaan jasa (termasuk pelacuran di daerah tersebut di mana sekitar 15\% dari jumlah penduduk positif mengidap HIV, van Haaften 1995).

Kontraktor - Kontraktor lokal yang menjalankan operasi pembalakan hutan dalam skala kecil atau menerapkan usaha lain yang berkaitan dengan kehutanan untuk perusahaan yang lebih besar.

Pejabat perusahaan - Orang-orang yang bekerja untuk perusahaan pembalakan kayu berskala besar, biasanya tempat kerjanya agak jauh dari hutan, tetapi pengaruhnya cukup besar dalam pengelolaan hutan.

Pejabat kehutanan - Orang-orang yang bekerja untuk pemerintah (Departemen Kehutanan, SODEFOR, dll.) yang mungkin juga secara fisik berada jauh dari hutan.

[Warga negara Nasional - Peran orang-orang ini tidak diselidiki di Pantai Gading, tetapi mereka mungkin mempunyai kepentingan yang mungkin semakin meningkat terhadap Hutan Lindung.]

[Pemerhati lingkungan - Hanya sedikit pemerhati lingkungan di Pantai Gading, tetapi relevansi mereka mungkin semakin meningkat, yang didukung oleh meningkatnya perhatian internasional terhadap hutan-hutan di Pantai Gading.]

\footnotetext{
${ }^{26}$ De Bruijn dan van Dijk 1995 membahas berbagai masalah kelangsungan hidup di Mali
} yang membuat jenis sistem jaminan sosial ini begitu penting 


\section{OLYMPIC NATIONAL FOREST, BUSHLER BAY, WASHINGTON, USA $^{27}$}

Bushler Bay, di negara bagian Washington, merupakan kelompok masyarakat di Olympic Peninsula yang berjumlah 2000 orang. Tempat ini merupakan markas besar US Forest Service yang mengelola daerah yang berbatasan dengan Olympic National Forest, hutan hujan sedang di kawasan yang didominasi oleh pinus, Douglas dan Hemlock (lihat Kirk with Franklin 1992, untuk deskripsi ekologinya). Masyarakat ini secara mencolok terbagi menjadi masyarakat lokal (pembalak hutan, nelayan, petani tiram, dan para pengusaha) dan karyawan umum (pekerja sekolah, para pegawai US National Park Service, US Forest Service, Washinton State Shellfish Laboratory dan Washington State Fish Hatchery;Colfer bersama Colfer 1978).

Beberapa tahun terakhir ini, terjadi konflik yang semakin memuncak di daerah ini disebabkan oleh perubahan kebijakan dan gagasan dalam mengelola hutan (Lien 1991). Isu-isu lingkungan (ditandai oleh keprihatinan terhadap burung hantu berbintik dan marbled murrelet) yang dipertentangkan dengan kepentingan mata pencaharian dan cara hidup masyarakat pembalakan hutan di kawasan tersebut (Dietrich 1992; Barber, Johnson dan Hafild 1994).

Pada tahun 1995, US Forest Service menutup seluruh Bushler Bay Ranger District di Olympic National Forest untuk pembalakan hutan. Jumlah pembalak hutan di kalangan masyarakat tersebut semakin berkurang, sehingga pengusaha skala kecil yang tersisa harus mencari pembalak hutan dari

27 olfer melakukan penelitian etnografi di Bushler Bay, Washington nama samaran antara tahun 1972 dan 1975, terlibat lebih lanjut dengan masyarakat tersebut sampai tahun 1980 Kunjungan singkat dilakukannya lagi pada tahun 1994, 1995 dan 1997 
masyarakat lain yang ada di Peninsula. ${ }^{28}$ Pengemudi truk pengangkut kayu mengeluh karena mereka harus mengemudi lebih jauh ke bagian barat negara bagian tersebut. Masyarakat pembalak hutan yang berkembang pada tahun 1970-an, pada tahun 1990-an merupakan rumah untuk masyarakat yang mendapat tunjangan sosial dan untuk orang-orang yang sudah pensiun .

Perbedaan penting dari dua contoh sebelumnya adalah hak atas lahan yang jelas dan ideologi negara yang mendukung keikutsertaan masyarakat dalam mengelola hutan (sekalipun agak bersifat sedikit teoritis karena lokasi yang letaknya jauh dari tempat pengambilan keputusan akhir). ${ }^{29}$ Seperti di Indonesia dan di Pantai Gading, terdapat rasa ketidakpastian mengenai masa depan, baik dari segi produksi kayu, lingkungan dan masyarakat.

Kelompok-kelompok stakeholder berikut ini berperanan penting di sana. ${ }^{30}$

Pembalak hutan - Istilah ini mencakup orang-orang yang terlibat dalam penebangan pohon dan pengangkutan kayu beserta keluarga mereka. Tentu saja kelompok ini adalah inti dari suatu gaya hidup di mana pembalakan hutan terkait erat dengan keberanian dan kemandirian

${ }^{28}$ Dalam kegiatan operasi pembalakan hutan skala kecil yang diamati pada tahun 1995 di lahan pribadi, olfer me a ancarai lima orang pekerja, dan hanya satu orang yang berasal dariBushler Bay majikannya

${ }^{29}$ Lihat analisis Smith dan Steel 1995 tentang pengambilan keputusan, partisipasi, dan kekuasaan dari masyarakat yang hidup mengandalkan hutan di Pacific North est oast, Amerika Serikat

${ }^{30}$ Buku terkenal dari Dietrich s 1993 memilih penebang, biologi an, pengemudi truk, pemerhati lingkungan, rimba an, dan kandidat, yang masing-masing dituliskan dalam setiap bab, untuk menggambarkan kontroversi yang menyelubungi hutan Pacific North est 
(Colfer 1977). Pendidikan formal tidak dianggap bernilai tinggi dan orang-orang yang mengejar ijasah tidak begitu dihargai. ${ }^{31}$ Keluarga pembalak hutan memiliki riwayat yang telah berakar di dalam masyarakatnya, berkerabat dekat dengan anggota masyarakat lainnya, dan memiliki tanah (dan hutan) daripada stakeholder lainnya.Mereka juga lebih banyak memanfaatkan hutan sebagai sumber makanan tambahan (berburu, menangkap ikan, mengumpulkan jamur, buah berry, dan hasil hutan nonkayu lainnya).

Pengusaha berskala kecil - Orang-orang ini menjalankan perusahaan yang mendukung industri pembalakan hutan dan sering termasuk mantan pembalak hutan yang telah berhasil dalam hidup. Mereka juga mungkin memiliki perusahaan pembalakan hutan yang menawarkan kontrak untuk membalak hutan secara perseorangan dan/atau (sebelumnya) dengan US Forest Service.

Pemerhati lingkungan - Dalam konteks Bushler Bay, orang-orang ini dapat digambarkan sebagai bagian dari gerakan Kembali ke Bumi . Banyak di antara yang berpendidikan baik dengan latar belakang perkotaan yang mencari kehidupan yang lebih tenang, lebih dekat dengan alam. Mereka seperti keluarga pembalak hutan, mungkin lebih mengandalkan hutan sepenuhnya sebagai sumber makanan tambahan. Mereka juga sering konflik dengan keluarga pembalak hutan dan US Forest Service tentang persoalan pengelolaan sumber daya alam (bandingkan dengan Lien 1991). Pemerhati lingkungan yang berada dalam jarak jauh jugamempunyai pengaruh yang kuat di Bushler Bay,

\footnotetext{
${ }^{31}$ Dalam kunjungan ke dekat regon pada tahun 1998, pengemudi truk kayu menggunakan kaos yang dihiasi dengan tulisan jika kamu bukan seorang pembalak hutan, kamu bukan kotoran, yang secara ringkasmenyimpulkan pandanganini
} 
melalui berbagai cara (pemberian suara, penulisan surat, demonstrasi, pengumpulan uang). ${ }^{32}$

Para pegawai pemerintah - Orang-orang ini terutama adalah para pegawai US Forest Service dan US Park Service. Bushler Bay, Washington dikelilingi oleh National Forest (hutan negara) dan National Park (taman nasional) yang dikelola oleh pemerintah. Pegawai sipil dengan organisasi ini beserta dengan keluarga mereka - yang meliputi separuh dari jumlah penduduk pada tahun 1970-an - cenderung berasal dari daerah lain, sering bekerja dengan Dinas Taman atau Hutan dalam pencariannya akan gaya hidup di alam terbuka. Mereka menemukan malah sebaliknya, bahwa hidup mereka penuh dengan membolak-balik kertas yang diremehkan oleh tetangga mereka. Sebagian besar terdiri dari kelas menengah, orang-orang yang giat, yang menghargai pendidikan, kesopanan, sikap yang tidak berlebihlebihan dalam segala sesuatu. Mereka cenderung merendahkan penduduk setempat yang dipandang sebagai kelas bawah, tidak berpendidikan dan murahan (Colfer bersama Colfer 1978; Colfer 1977). Namun sekarang, mereka juga melihat pembalak hutan sebagai orang yang ikut bertanggung jawab atas kerusakan lingkungan.

Politisi - Orang-orang ini ikut ambil bagian dalam pengambilan keputusan untuk tingkat negara bagian dan nasional. Mereka mewakili para pemilihnya dalam menyalurkan keinginan mereka. Mereka secara terus-menerus didebat oleh pemerhati lingkungan, di satu pihak, dan

\footnotetext{
${ }^{32}$ Dennis Dykstra kom pri uli 1995 semula menunjukkan pentingnya pemerhati lingkungan yang jauh berada dari hutan sebagai stakeholders Alasannya adalah bah a meskipun ketergantungan mereka pada hutan relatif lebih rendah daripada orang-orang yang tinggal di dalam dan di sekeliling hutan; pengaruh mereka yang kuat terhadap pengelolaan mungkin akan lebihbesar lihatjugaSmith danSteel1995
} 
industri perkayuan di pihak lainnya, sehubungan dengan keadaan sepertidi Bushler Bay.

Warga negara nasional - Penduduk ini secara tidak langsung, tetapi nyata, berpengaruh nyata terhadap pengelolaan hutan. Seluruh penduduk Amerika Serikat, melalui pemungutan suara atau melalui penulisan surat kepada wakil-wakil pilihan mereka (politisi) dapat mempengaruhi pengelolaan Hutan Nasional atau Taman Nasional di mana saja. 
Tabel 1: Para stakeholder - Bushler Bay, Olympic National Forest, Washington, Amerika Serikat [Rekonstruksi mulai tahun 1970-1997]

\begin{tabular}{|l|c|c|c|c|c|c|c|}
\hline \multicolumn{1}{|c|}{ Dimensi } & $\begin{array}{c}\text { Para } \\
\text { pembalak }\end{array}$ & $\begin{array}{c}\text { Pengusaha } \\
\text { berskala } \\
\text { kecil }\end{array}$ & $\begin{array}{c}\text { Pemer- } \\
\text { hati ling- } \\
\text { kungan }\end{array}$ & $\begin{array}{c}\text { Pega ai } \\
\text { peme- } \\
\text { rintah }\end{array}$ & $\begin{array}{c}\text { Para } \\
\text { politikus }\end{array}$ & $\begin{array}{c}\text { Konsu- } \\
\text { men }\end{array}$ & $\begin{array}{c}\text { Warga } \\
\text { negara } \\
\text { nasional }\end{array}$ \\
\hline Kedekatan & 1 & 1 & 1 & 1 & 3 & 3 & var \\
\hline Hak-hak yang sudah ada & 2 & 2 & 3 & 2 & 3 & 3 & 3 \\
\hline Ketergantungan & 2 & 2 & 2 & 2 & 3 & var & 3 \\
\hline Kemiskinan & 2 & 2 & 2 & 2 & 2 & var & var \\
\hline Pengetahuan indijenus & 1 & 2 & 2 & 3 & 3 & 3 & 3 \\
\hline Integrasihutan/budaya & 1 & 1 & 1 & 3 & 3 & var & 3 \\
\hline Defisit kekuasaan & 1 & 2 & 2 & 3 & 3 & var & var \\
\hline NILAI TENGAH & $\mathbf{1 , 4 3}$ & $\mathbf{1 , 7 1}$ & $\mathbf{1 , 8 6}$ & $\mathbf{2 , 2 9}$ & $\mathbf{2 , 8 6}$ & $\mathbf{3 , 0 0}$ & $\mathbf{3 , 0 0}$ \\
\hline
\end{tabular}

1= tinggi; $\quad 2=$ sedang; $3=$ rendah

Matriks ini disusun oleh Colfer, berdasarkan penelitian etnografi selama tiga tahun antara tahun 1973 dan 1976, dengan beberapa kunjungandanyangterakhirpadatahun 1997.

Tabel 2: Para stakeholder - Kalimantan Timur, Indonesia [Maret 1995]

\begin{tabular}{|l|l|l|l|l|l|l|l|l|l|l|}
\hline \multicolumn{1}{|c|}{ Dimensi } & Dayak & Kutai & $\begin{array}{c}\text { Trans- } \\
\text { migran }\end{array}$ & $\begin{array}{c}\text { Pekerja } \\
\text { hutan }\end{array}$ & $\begin{array}{c}\text { Pengusa- } \\
\text { ha skala } \\
\text { kecil }\end{array}$ & $\begin{array}{c}\text { Pegawai Pemerhati } \\
\text { peru- } \\
\text { sahana }\end{array}$ & $\begin{array}{c}\text { Pegaing- } \\
\text { kungan }\end{array}$ & $\begin{array}{c}\text { Wehu- } \\
\text { tanan }\end{array}$ & $\begin{array}{c}\text { Warga } \\
\text { negara }\end{array}$ & $\begin{array}{c}\text { Kon- } \\
\text { sumen }\end{array}$ \\
\hline Kedekatan & 1 & 1 & 1 & 122 & 33 & 3 & 3 & & & \\
\hline Hak-hak yang sudah ada & 1 & 1 & var & 3 & var & 3 & 3 & 3 & 3 & 3 \\
\hline Ketergantungan & 1 & 1 & 1 & 1 & 1 & 1 & 1 & 2 & 2 & 3 \\
\hline Kemiskinan & 1 & 1 & 1 & 1 & 2 & 2 & 2 & 2 & var & var \\
\hline Pengetahuanindijenus & 1 & 1 & var & var & 2 & 3 & 3 & 3 & 3 & 3 \\
\hline Integrasihutan/budaya & 1 & 1 & var & var & 2 & 3 & 3 & 2 & 3 & 3 \\
\hline Defisit kekuasaan & 1 & 1 & 1 & 1 & 2 & 3 & 3 & 3 & var & var \\
\hline NILAI TENGAH & $\mathbf{1 , 0 0}$ & $\mathbf{1 , 0 0}$ & $\mathbf{1 , 0 0}$ & $\mathbf{1 , 4 0}$ & $\mathbf{1 , 8 3}$ & $\mathbf{2 , 4 3}$ & $\mathbf{2 , 5 7}$ & $\mathbf{2 , 5 7}$ & $\mathbf{2 , 8 0}$ & $\mathbf{3 , 0 0}$ \\
\hline
\end{tabular}

1= tinggi; 2 =sedang; $3=$ rendah

Matriks ini disusun oleh Colfer, berdasarkan penelitian etnografi selama satu tahun (1979-1980), merupakanpengujianantardisiplinK\&I(1995), danhasilkunjunganselamatahun1997. 
Tabel 3: Para stakeholder - Bossematié, Pantai Gading [ uni 1995]

\begin{tabular}{|l|l|l|l|l|l|l|l|l|l|l|}
\hline \multicolumn{1}{|c|}{ Dimensi } & $\begin{array}{c}\text { Agni } \\
\text { lokal }\end{array}$ & $\begin{array}{c}\text { Peker- } \\
\text { ja } \\
\text { hutan }\end{array}$ & $\begin{array}{c}\text { Alloch- } \\
\text { tones } \\
\text { pendu- } \\
\text { duk asli }\end{array}$ & $\begin{array}{c}\text { Allo- } \\
\text { gens } \\
\text { orang } \\
\text { asing }\end{array}$ & $\begin{array}{c}\text { Tache- } \\
\text { rons } \\
\text { Kontrak } \\
\text { tor) }\end{array}$ & $\begin{array}{c}\text { Pegawai } \\
\text { kehu- } \\
\text { tanan }\end{array}$ & $\begin{array}{c}\text { Warga } \\
\text { negara }\end{array}$ & $\begin{array}{c}\text { Pegawai Pemer- } \\
\text { perusa- } \\
\text { haan }\end{array}$ & $\begin{array}{c}\text { hati ling- } \\
\text { kungan }\end{array}$ \\
men \\
Kedekatan & 1 & 1 & 1 & 1 & 2 & 3 & 3 & 3 & 3 & 3 \\
\hline Hak-hakyangsudahada & 1 & var & 2 & 3 & var & 2 & 2 & 3 & 3 & 3 \\
\hline Ketergantungan & 1 & 1 & 1 & 1 & 2 & 1 & 3 & 1 & 3 & 3 \\
\hline Pengetahuan indijenus & 1 & 2 & 2 & 2 & 2 & 3 & 3 & 3 & 3 & 3 \\
\hline Integrasi hutan/budaya & 1 & 2 & 2 & 2 & var & 3 & 2 & 3 & 2 & 3 \\
\hline Defisit kekuasaan & 2 & 1 & 1 & 1 & 2 & 3 & var & 3 & 3 & var \\
\hline NILAI TENGAH & $\mathbf{1 , 1 7}$ & $\mathbf{1 , 4 0}$ & $\mathbf{1 , 5 0}$ & $\mathbf{1 , 6 7}$ & $\mathbf{2 , 0 0}$ & $\mathbf{2 , 5 0}$ & $\mathbf{2 , 6 0}$ & $\mathbf{2 , 6 7}$ & $\mathbf{2 , 8 3}$ & $\mathbf{3 , 0 0}$ \\
\hline
\end{tabular}

$1=$ tinggi; $\quad 2=$ sedang; $3=$ rendah

Matriks ini disusun oleh Colfer, berdasarkan sebuah pengujian antardisiplin K\&I pada bulan Juni 1995. Penilaian Colfer dikritik oleh Ahui Anvo, Heleen van Haaften, Charles Huttel, Jean Claude Koffi Konan, PatriceMengin-LecreulxdanAnatole N'Guessan. 


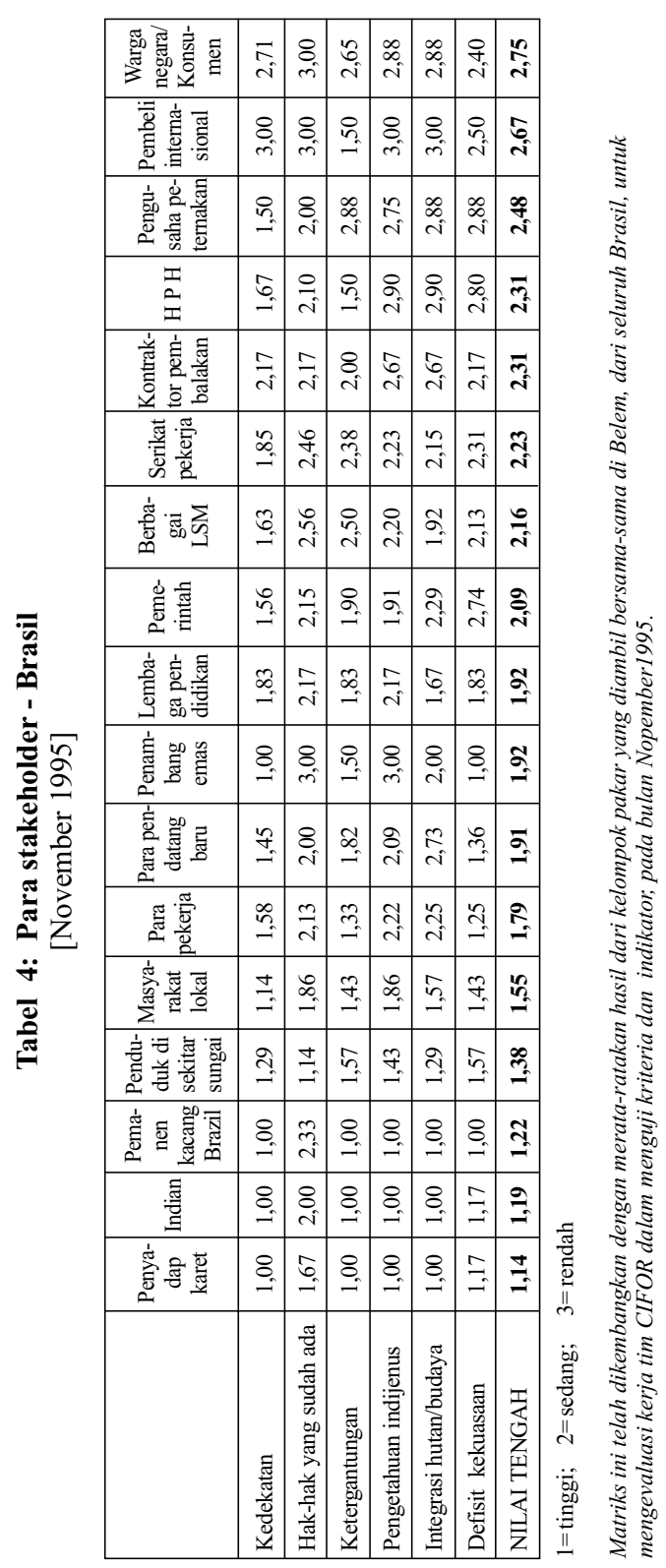


Tabel 5: Para stakeholder - Trinidad

[a al tahun 1998]

\begin{tabular}{|l|c|c|c|c|c|c|c|c|c|c|c|}
\hline \multicolumn{1}{|c|}{ Dimensi } & $\begin{array}{c}\text { Peme- } \\
\text { gang } \\
\text { ijin } \\
\text { s asta }\end{array}$ & $\begin{array}{c}\text { Peker- } \\
\text { ja } \\
\text { hutan }\end{array}$ & $\begin{array}{c}\text { Peng- } \\
\text { gerga- } \\
\text { jian }\end{array}$ & $\begin{array}{c}\text { Peng- } \\
\text { huni } \\
\text { asing }\end{array}$ & $\begin{array}{c}\text { Para } \\
\text { pem- } \\
\text { buru }\end{array}$ & $\begin{array}{c}\text { Pega- } \\
\text { ai } \\
\text { kehu- } \\
\text { tanan }\end{array}$ & $\begin{array}{c}\text { Tan- } \\
\text { teak } \\
\text { peru- } \\
\text { sahaan }\end{array}$ & $\begin{array}{c}\text { Pega- } \\
\text { Wai } \\
\text { konser- } \\
\text { vasi }\end{array}$ & $\begin{array}{c}\text { Eko- } \\
\text { pari i- } \\
\text { sata }\end{array}$ & $\begin{array}{c}\text { Konsu- } \\
\text { men }\end{array}$ & $\begin{array}{c}\text { Warga } \\
\text { negara }\end{array}$ \\
\hline Kedekatan & 1,33 & 1,44 & 1,67 & 1,22 & 1,78 & 1,89 & 1,67 & 2,11 & 1,89 & 2,56 & 2,44 \\
\hline Hak-hak yang sudah ada & 1,89 & 2,11 & 1,67 & 1,78 & 1,56 & 1,89 & 1,78 & 2,11 & 2,89 & 2,44 & 2,44 \\
\hline Ketergantungan & 1,22 & 1,33 & 1,11 & 1,56 & 1,89 & 1,44 & 1,33 & 2,33 & 2,11 & 2,33 & 2,56 \\
\hline Pengetahuan indijenus & 1,44 & 1,67 & 1,78 & 2,44 & 1,89 & 1,56 & 2,33 & 2,00 & 2,22 & 2,67 & 2,78 \\
\hline Integrasi hutan/budaya & 1,56 & 1,89 & 1,89 & 2,11 & 2,00 & 1,78 & 2,44 & 2,22 & 2,44 & 2,56 & 2,89 \\
\hline Defisit kekuasaan & 1,67 & 1,67 & 2,00 & 1,33 & 1,67 & 2,78 & 2,56 & 2,22 & 1,89 & 2,33 & 2,44 \\
\hline NILAI TENGAH & $\mathbf{1 , 5 2}$ & $\mathbf{1 , 6 9}$ & $\mathbf{1 , 6 9}$ & $\mathbf{1 , 7 4}$ & $\mathbf{1 , 8 0}$ & $\mathbf{1 , 8 9}$ & $\mathbf{2 , 0 2}$ & $\mathbf{2 , 1 7}$ & $\mathbf{2 , 2 4}$ & $\mathbf{2 , 4 8}$ & $\mathbf{2 , 5 9}$ \\
\hline
\end{tabular}

1=tinggi; $2=$ sedang; $3=$ rendah

Matriks ini disusun oleh Mario Günter, berdasarkan masukan dari para pakar di Trinidad, selama tahun 1998.

Tabel 6: Para stakeholder - Boise National Forest, Boise, Idaho, Amerika Serikat [ uni 1998]

\begin{tabular}{|l|c|c|c|c|c|c|l|l|l|l|}
\hline \multicolumn{1}{|c|}{ Dimensi } & $\begin{array}{c}\text { Perusa } \\
\text { haan } \\
\text { H P H }\end{array}$ & $\begin{array}{c}\text { Pengum- } \\
\text { pHINK }\end{array}$ & $\begin{array}{c}\text { Lokasi } \\
\text { perusaha- } \\
\text { an kayu }\end{array}$ & $\begin{array}{c}\text { Pemburu/ } \\
\text { peman- } \\
\text { cing }\end{array}$ & $\begin{array}{c}\text { Off } \\
\text { Roaders }\end{array}$ & $\begin{array}{c}\text { Pegawai } \\
\text { konser- } \\
\text { vasi }\end{array}$ & S S & $\begin{array}{c}\text { Boise- } \\
\text { ascade }\end{array}$ & $\begin{array}{c}\text { Dep. } \\
\text { Per- } \\
\text { ikanan }\end{array}$ & $\begin{array}{c}\text { Dep } \\
\text { Perta- } \\
\text { nahan } \\
\text { Idaho }\end{array}$ \\
\hline Kedekatan & 1 & 2 & 1 & 2 & 1 & 2 & 2 & 2 & 2 & 2 \\
\hline Hak-hak yang sudah ada & 1 & 1 & 1 & 2 & 2 & 3 & 3 & 3 & 3 & 3 \\
\hline Ketergantungan & 1 & 2 & 2 & 2 & 3 & 2 & 2 & 1 & 2 & 2 \\
\hline Pengetahuan indijenus & 1 & 1 & 1 & 1 & 2 & 3 & 3 & 3 & 3 & 3 \\
\hline Integrasi hutan/budaya & 1 & 1 & 2 & 1 & 2 & 1 & 2 & 3 & 3 & 3 \\
\hline Defisit kekuasaan & 1 & 1 & 2 & 2 & 2 & 2 & 3 & 3 & 3 & 3 \\
\hline Colfer & $\mathbf{1}$ & $\mathbf{1 , 3 3}$ & $\mathbf{1 , 5 0}$ & $\mathbf{1 , 6 7}$ & $\mathbf{2 , 0 0}$ & $\mathbf{2 , 1 7}$ & $\mathbf{2 , 5 0}$ & $\mathbf{2 , 5 0}$ & $\mathbf{2 , 6 7}$ & $\mathbf{2 , 6 7}$ \\
\hline Holt & $\mathbf{1}$ & $\mathbf{1 , 3 3}$ & $\mathbf{1 , 1 7}$ & $\mathbf{1 , 6 7}$ & $\mathbf{2 , 1 7}$ & $\mathbf{2 , 3 3}$ & $\mathbf{2 , 5 0}$ & $\mathbf{2 , 5 0}$ & $\mathbf{2 , 5 0}$ & $\mathbf{2 , 6 7}$ \\
\hline Livingston & $\mathbf{1}$ & $\mathbf{1 , 2 0}$ & $\mathbf{1 , 3 3}$ & $\mathbf{1 , 6 0}$ & $\mathbf{2 , 0 0}$ & $\mathbf{2 , 1 7}$ & $\mathbf{2 , 5 0}$ & $\mathbf{2 , 5 0}$ & $\mathbf{2 , 6 7}$ & $\mathbf{2 , 4 0}$ \\
\hline
\end{tabular}

1=tinggi $; \quad 2=$ sedang; $\quad 3=$ rendah 
Colfer mengembangkan matriks ini pada bulan Juni 1998. Livington menambahkan stakeholder lain yang penting, bukan-industrial, kepemilikan hutan swasta dan diberikan skor rata-rata untuk semua 1,60. Kelompok ini tidak termasuk pengujian Boise K\&I. Ladd Livingston bekerja untuk Departmen Pertanahan diCoeurd'Alene,Idaho; dan Brad Holt bekerjauntuk Boise Cascade Corporation di Boise,Idaho.

\section{Tabel 7: Para stakeholder - Porto de Moz dan Bom Jesus, Brasil} [Agustus 1998]

\begin{tabular}{|l|c|c|c|c|c|c|c|}
\hline \multicolumn{1}{|c|}{ Dimensi } & $\begin{array}{c}\text { Penduduk } \\
\text { baru } \\
\text { pria }\end{array}$ & $\begin{array}{c}\text { Penduduk } \\
\text { baru } \\
\text { anita }\end{array}$ & $\begin{array}{c}\text { Pengusaha } \\
\text { peternakan } \\
\text { sapi }\end{array}$ & $\begin{array}{c}\text { Pemilik } \\
\text { perusahaan } \\
\text { H P H }\end{array}$ & $\begin{array}{c}\text { Pengendara } \\
\text { truk peng- } \\
\text { angkut kayu }\end{array}$ & $\begin{array}{c}\text { Lembaga } \\
\text { IBAMA }\end{array}$ & $\begin{array}{c}\text { Lembaga } \\
\text { IN } \\
\text { A }\end{array}$ \\
\hline Kedekatan & 1 & 1 & 3 & 3 & 3 & 3 & 3 \\
\hline Hak-hak yang sudah ada & 1 & 1 & 2 & 3 & 3 & 3 & 3 \\
\hline Ketergantungan & 1 & 1 & 2 & 3 & 3 & 3 & 3 \\
\hline Kemiskinan & 2 & 2 & 3 & 3 & 3 & 3 & 3 \\
\hline Pengetahuan indijenus & 1 & 1 & 2 & 3 & 3 & 3 & 3 \\
\hline Integrasi hutan/budaya & 2 & 3 & 3 & 3 & 3 & 3 & 3 \\
\hline Defisit kekuasaan & 2 & 2 & 3 & 3 & 3 & 3 & 3 \\
\hline NILAI TENGAH & $\mathbf{1 , 4 3}$ & $\mathbf{1 , 5 7}$ & $\mathbf{2 , 5 7}$ & $\mathbf{3 , 0 0}$ & $\mathbf{3 , 0 0}$ & $\mathbf{3 , 0 0}$ & $\mathbf{3 , 0 0}$ \\
\hline
\end{tabular}

1= tinggi; $\quad 2=$ sedang; $3=$ rendah

Matriks ini disusun oleh Noemi Miyasaka Porro dan Roberto Porro, berdasarkan penilaian ahli mereka, antarabulanJulidanSeptember 1998. 


\section{SistemCGIAR}

The Consultative Group on International Agricultural Research (CGIAR) adalah suatu asosiasi informal yang terdiri dari 41 organisasi donor dari sektor publik dan swasta yang mendukung jaringan enam belas lembaga penelitian internasional di bidang pertanian, di mana CIFOR merupakan anggota terbaru. Asosiasi ini didirikan pada tahun 1971. Pusat-pusat CGIAR merupakan bagian sistem penelitian global di bidang pertanian yang berusaha menerapkan kemampuan ilmiah internasional untuk menyelesaikan masalah-masalah yang dihadapi olehmasyarakatmiskin di dunia.

\section{CIFOR}

CIFOR adalah bagian sistem CGIAR dengan tugas khusus untuk menanggapi kepedulian global tentang dampak kerusakan dan kehilangan hutan terhadap kondisi sosial, lingkungan dan ekonomi masyarakat. CIFOR beroperasi melalui berbagai kemitraan yang sangat terdesentralisasi dengan lembaga-lembaga dan/atau individu terpenting di seluruh negara industri dan negara yang sedang berkembang. Sifat dan jangka waktu kemitraan ini ditentukan oleh masalahmasalah penelitian khusus yang dihadapi. Agenda penelitian ini terus-menerus dikaji dan selalu mengalami perubahan ketika para mitra menemukan berbagai masalah dan peluang baru. 


\section{Siapa yang Perlu Dipertimbangkan? Menilai Kesejahteraan}

Manusia dalam Pengelolaan Hutan Lestari menyajikan alat yaitu Matriks Siapa yang Perlu Dipertimbangkan, untuk membedakan pihak-pihak yang berkepentingan dengan pengelolaan hutan (forest actors) , atau orang-orang yang kesejahteraannya terkait erat dengan pengelolaan hutan, dari stakeholder lainnya. Para penulis lebih memusatkan perhatian kepada para pihak yang terlibat dalam pengelolaan hutan dalam upaya untuk mengembangkan pengelolaan hutan lestari $(\mathrm{PHL})$. Selain menyajikan tujuh dimensi untuk membedakan pihak-pihak ini dari stakeholder lainnya, kami memaparkan suatu teknik pemberian skor sederhana bagi para pengelola hutan resmi untuk menetapkan kesejahteraan siapa saja yang seharusnya menjadi bagian integral PHL di suatu lokasi tertentu. Dengan mengacu pada kriteria dan indikator (K\&I) yang ditetapkan oleh Center for International Forestry Research (CIFOR), kami membuat tiga contoh set tentang stakeholder di Indonesia, Pantai Gading dan Amerika Serikat (AS), dan melengkapinya dengan Matriks Siapa yang Perlu Dipertimbangkan dari tujuh pengujian yang disajikan dalam lampiran. 